\title{
Why are bird migration dates shifting? A review of weather and climate effects on avian migratory phenology
}

\author{
Oscar Gordo* \\ Departamento de Ecología Evolutiva, Museo Nacional de Ciencias Naturales (CSIC), C/ José Gutiérrez Abascal, 2 , \\ 28006 Madrid, Spain
}

\begin{abstract}
Many studies have reported statistically significant associations between bird migratory phenology and climatic variables, and, consequently, it is mostly accepted that recent shifts in migration dates are a reaction to present climate change. Impacts of weather and climate on departure date, progression and stopover frequency and duration have been reviewed in order to explain the current knowledge of climatic mechanisms underlying such phenological shifts. Climate in departure areas can affect population phenology via the size of the returning population. In a short-term sense, ecological conditions can affect acquisition of migratory body condition during the days preceding departure. Migratory phenology can also be affected by quality and quantity of replaced feathers during moult. Adverse weather conditions en route strongly hinder the progression of individuals and even force them to land. The time spent on stopovers will greatly depend on the ecological conditions there and the opportunities for refuelling. Temperature is by far the climatic variable most frequently related to avian phenology. The use of climatic indices is spreading because they have the advantage of synthesizing weather conditions into a single variable. Remote sensing is probably the best option to explore ecological conditions in areas used by migratory species. Most of the climatic variables employed are from the arrival area, while climate from passage or departure areas is rarely assessed. The overwhelming majority of studies have used variables defined by months, while the use of periods designed ad hoc according to species' biology is almost anecdotal. It can be concluded that further research is needed to disentangle the true relevance of each type of climatic variable over avian migratory phenology during each phase of migration.
\end{abstract}

KEY WORDS: Arrival date $\cdot$ Bird migration $\cdot$ Climate change $\cdot$ Phenology

\section{RECENT CHANGES IN MIGRATION DATES}

The alteration of climatic patterns in recent decades has already had an impact on organisms (Peñuelas \& Filella 2001, IPCC 2002, Walther et al. 2002, Parmesan \& Yohe 2003, Root et al. 2003, 2005, Parmesan 2006). One of the most evident changes has been the alteration of seasonal timing in northern latitudes (Sparks \& Crick 1999, Sparks \& Menzel 2002). At present, spring is beginning earlier, while autumn arrival is being delayed (Menzel et al. 2006). The potential effects of such changes on organisms' life-cycles are large and range from ecosystem functioning to species' competitive abilities (Walther et al. 2002, Visser \& Both 2005, Parmesan 2006).

In the case of migratory bird species, a growing number of studies have reported shifts in the timing of their migrations during the last decades (Sparks 1999, Sanz 2002, Root et al. 2003, Crick 2004, Lehikoinen et al. 2004, Crick \& Sparks 2006, Jian-bin et al. 2006, Rubolini et al. 2007b, this issue). In most cases, a trend toward earlier spring arrival of birds has been detected at European and North American breeding grounds, especially since the 1970s. Hence, migratory birds are 
advancing their arrivals. The advancement of spring migratory phenology has been attributed to climate change, with special regard to global warming. In most cases, a negative relationship has been found between arrival dates and spring temperatures (Lehikoinen et al. 2004, Root et al. 2005, Gienapp et al. 2007, this issue), i.e. birds arrive earlier when spring temperatures are higher. Higher temperatures also advance the spring phenology of plants and insects in the European and North American passage and breeding areas (Menzel et al. 2006, Gordo \& Sanz 2006b, Schwartz et al. 2006) which may improve ecological conditions for migration through these temperate regions due to increased food availability (Huin \& Sparks 1998, Hüppop \& Hüppop 2003, Ahola et al. 2004, Vähätalo et al. 2004, Both et al. 2005, Mitrus et al. 2005, Hüppop \& Winkel 2006, Rainio et al. 2006). Warmer springs are also related to more benign weather, thus meteorological conditions for travel are improved (Forchhammer et al. 2002, Boyd 2003, Tryjanowski et al. 2002, Vähätalo et al. 2004, Marra et al. 2005, Zalakevicius et al. 2006, Sinelschikova et al. 2007).

However, those changes recorded in the arrival date at the southern fringe of the breeding distributions (such as the Mediterranean region for trans-Saharan migrants; Gordo \& Sanz 2005, 2006a, Gordo et al. 2005, Rodríguez-Teijeiro et al. 2005, Jonzén et al. 2006, Rubolini et al. 2007a, Saino et al. 2007, this issue) cannot be attributed to the previously cited mechanisms. There, individuals do not pass through Europe or North America, and, consequently, they cannot be affected by conditions in temperate latitudes. Conditions during the spring in Europe and North America are overrepresented, because the overwhelming majority of studies have been conducted in northern latitudes (see Fig. 1). Individuals must fly for days or weeks through Europe or North America before reaching these northern localities (e.g. Southern 1938). In these cases, arrival dates will indeed be strongly driven by weather and climatic fluctuations occurring during the end of their travel at European and North American grounds.

The advancement of spring arrival is also expected based on the effects of climate change on the balance between the benefits and costs of the arrival date (Jonzén et
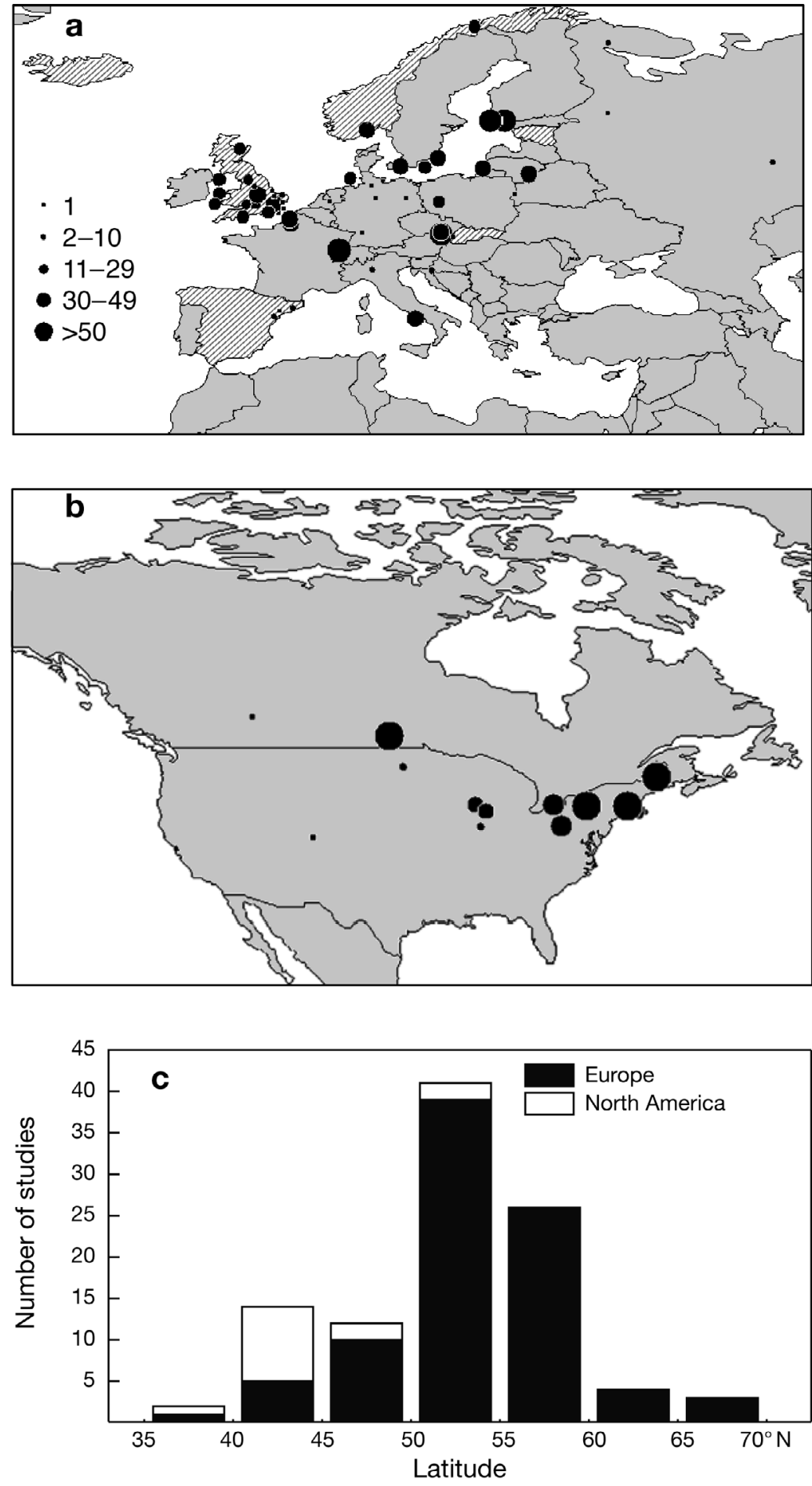

Fig. 1. Locations of recent studies on long-term changes in bird migratory phenology and climate change in Europe (a) and North America ( $b$; see reference list). Dot size indicates the number of species analyzed at each site. Countries with diagonal shading indicate studies that used some kind of monitoring network covering several localities at a national level (Huin \& Sparks 1998, 2000, Sparks \& Braslavská 2001, Forchhammer et al. 2002, Boyd 2003, Gordo \& Sanz 2006a). (c) Distribution of studies according to latitude ( $5^{\circ}$ intervals) in the Northern Hemisphere. Solid bars: European studies; open bars: North American studies 
al. 2007a). An early arrival at the breeding grounds has many benefits for individuals: best breeding territories, increased chances to obtain a mate, better quality mates, increased chances for extra clutches and higher survival rates of offspring (Møller 1994, Kokko 1999, Forstmeier 2002, Dunn 2004, Bearhop et al. 2005, Newton 2006). However, arrival date cannot be too early because of costs in terms of mortality due to the absence of suitable ecological conditions in the breeding grounds at the beginning of spring (e.g. low temperatures, food scarcity; Brown \& Brown 2000, Jonzén et al. 2007a, Newton 2007). With the advancement of spring phenology, food supplies have become available at earlier dates and the mortality rate between arrival and breeding is reduced due to milder weather (Møller 2004). Therefore, advancement of arrival dates can also be interpreted as the response of individuals in order to optimize the benefits of early arrival.

Nevertheless, some populations have not changed (or have even delayed) their arrival dates during the last few decades, in spite of the favourable changes in spring climate and phenology in their breeding grounds (e.g. Inouye et al. 2000, Wilson et al. 2000, Both \& Visser 2001, Strode 2003, Gordo et al. 2005, Weidinger \& Král 2007). This fact would imply a maladaptive response under previous assumptions of the optimization hypothesis. However, this hypothesis is simplistic, since spring phenology at the breeding grounds cannot be the only pressure for the best adjustment of arrival dates. Migratory birds spread out their annual cycles over different geographical areas and, consequently, suffer several environmental changes in each of these areas (Coppack \& Both 2002). Therefore, it is necessary to examine other environmental pressures apart from those, such as the increase of temperature, recorded in the breeding grounds (Inouye et al. 2000, Saino et al. 2004b, 2007, Gordo et al. 2005, Both et al. 2006, Gordo \& Sanz 2006a, Sinelschikova et al. 2007, Sparks \& Tryjanowski 2007, this issue). Furthermore, the timing of life-cycle events of migratory birds is under the control of endogenous rhythms (Berthold 1996, Gwinner 1996), which could constrain the plasticity of responses of some species to climatic changes (Both \& Visser 2001). Finally, a population decline can override the advancement of spring migration due to a decrease in the likelihood of the first individuals' detection (Sparks et al. 2001, Tryjanowski et al. 2005, Croxton et al. 2006, Sparks et al. 2007).

There is a third mechanism by which spring arrival can be advanced. Individuals can change the locations of the wintering grounds. In Spain, the white stork Ciconia ciconia has advanced its arrival by 1 mo since the 1980s (Gordo \& Sanz 2006a), while the number of wintering individuals on the Iberian Peninsula has increased sharply since then (Molina \& Del Moral 2005). Bearhop et al. (2005) showed that blackcap Sylvia atricapilla males overwintering in Britain arrive earlier at their German breeding grounds than their conspecifics overwintering in Iberia. Indoor experiments with 3 trans-Saharan species (garden warbler Sylvia borin, common redstart Phoenicurus phoenicurus and pied flycatcher Ficedula hypoleuca) have demonstrated that phenotypic plasticity in response to novel photoperiodic conditions from northern wintering grounds could be the cause of such advancement (Coppack et al. 2003; see also Coppack \& Both 2002, Coppack \& Pulido 2004).

In the case of autumn migratory phenology, there has been evidence of delays and advances (Gatter 1992, Bezzel \& Jetz 1995, Sokolov et al. 1999, Bairlein \& Winkel 2001, Sparks \& Braslavská 2001, Sparks \& Mason 2001, Gilyazov \& Sparks 2002, Cotton 2003, Jenni \& Kéry 2003, Witt 2004, Hüppop \& Hüppop 2005, Mills 2005, Gordo \& Sanz 2006a, Tøttrup et al. 2006b, MacMynowski \& Root 2007, Peron et al. 2007, this issue Sparks et al. 2007). In contrast to spring arrival dates there is no clear picture, as temporal trends of autumn migratory dates are strongly species specific. The optimal migratory strategy would fall under different pressures between long- and short-distance migrants during autumn migration (Jenni \& Kéry 2003). Long-distance migrants should depart as early as possible to profit from the abundance peak of resources at the end of the summer and the beginning of the autumn in some of their tropical passage and/or wintering areas (e.g. the Sahel; Morel 1973). In the case of single-brood species with earlier spring arrivals and/or earlier breeding dates, an advancement of departures should be expected as a result of a shift in the whole annual cycle (Fig. 2; Ellegren 1990, Sokolov 2000, Bojarinova et al. 2002). However, the advancement of spring arrivals and/or breeding dates could paradoxically delay autumn departures in multiplebrood species, because they could profit from this shift in the annual cycle by increasing the proportion of pairs that can lay second or third clutches (Fig. 2; Møller 2002).

Short-distance migrants are under different evolutionary pressures as a result of the ecological characteristics of their wintering areas. Ecological conditions of wintering areas of short-distance migrants (e.g. Mediterranean basin for European species) improve throughout autumn thanks to abundant rainfall during this season and the consequent end of summer drought conditions. Therefore, an overly early arrival to the wintering grounds could be constrained by the poor ecological conditions at the end of the summer and their potential costs in terms of survival. However, costs of remaining at the breeding grounds increase as 


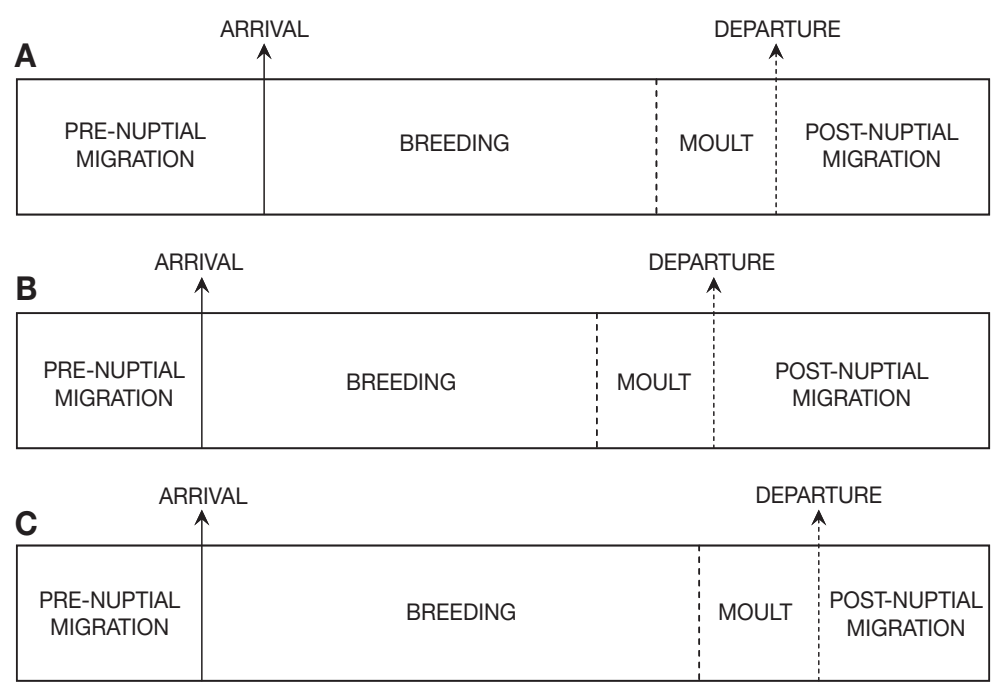

Fig. 2. (a) Main events in the life cycle of a migratory bird between pre- and post-nuptial migration. (b) An advancement of arrival date could advance departure date in single-brood, long-distance migrants. (c) However, in a multiple-brood, long-distance migrant, the advancement of arrival could extend breeding period through extra clutches and this fact could, in turn, delay departure

autumn progresses, because of unexpected adverse weather conditions (Newton 2007). Future climatic scenarios predict milder conditions in northern latitudes. Therefore, short-distance migrants could postpone (or even suppress) departure from their breeding grounds in order to profit from milder conditions in northern latitudes resulting from climate change (Bezzel \& Jetz 1995, Jenni \& Kéry 2003).

Other characteristics of autumn migration could mask temporal patterns on departure dates. In many species autumn departures are furtive, which hinders the precise detection of this phenomenon through observation. Observational records of autumn migration are also unprotected against the stronger mixture of individuals of different ages (juveniles and adults), sexes (males do not precede females) and natal origin (common in the southern areas of species' distribution) during autumn than during spring migration. Finally, the increase in temperatures is not homogeneous throughout the year, being especially slight or even non-existent in autumn (Karl et al. 1993, Easterling et al. 1997, Klein Tank et al. 2005). Hence, if autumn migration is affected by climate, but autumnal climate has not changed, then there are no climatic pressures to shift post-nuptial migratory phenology.

In summary, there is irrefutable evidence that avian migratory phenology has shifted during recent decades, but is climate change the true cause for such shifts? In spite of a consensus answering this question affirmatively (Sparks \& Crick 1999, Walther et al. 2002, Parmesan \& Yohe 2003, Root et al. 2003, Crick 2004, Root et al. 2005, Crick \& Sparks 2006), there is a lack of consensus regarding the mechanisms by which climatic changes can induce such shifts (Both 2007, Jonzén et al. 2007b), maybe as a result of the complex evolutionary pressures involved in the optimization of the arrival date together with geographical variability and a strong species-specific component of reported responses (Both \& te Marvelde 2007 this issue, Rubolini et al. $2007 \mathrm{~b}$ ). The aim of this paper is to review the potential climatic and weather mechanisms underlying the recently detected shifts in migratory dates. I pursue this objective in 2 steps in the present paper. First, I review direct and indirect effects of climate and weather from departure and passage areas on avian migratory phenology. Second, I review the use of climatic variables in recent studies of bird migratory phenology and climate change. By means of a quantitative assessment I want to highlight what we know and what we need to address in future research. I also identify the main advantages and pitfalls related to each type of climatic variable. The temporal patterns of advancements and delays are already well described (e.g. Lehikoinen et al. 2004); now is the time to delve into the underlying mechanisms for these patterns, especially those regarding climate and weather.

\section{EFFECTS OF CLIMATE AND WEATHER ON MIGRATORY PHENOLOGY}

The arrival date of a migrant bird will depend on what happens between individual departure from its origin to individual arrival at its destination. Therefore, arrival date will be a function of both the moment of departure and the time spent moving from its origin to its destination. The later the departure and the longer the time spent moving, the later the birds arrive. The time necessary to move between one place and another will, in turn, depend on: (1) the speed of progression through passage areas and (2) the total time spent at stopovers. Therefore, if we want to know what affects the arrival date of a migratory bird recorded at a certain place, we should examine those environmental elements that can potentially influence departure date from the origin, speed of progression (i.e. average movement rate between consecutive stopping places) and frequency (i.e. the number of stops during the whole journey) and length (i.e. the average duration of the stay in each refuelling site) of stopovers (Fig. 3).

Conditions at the end of the migratory journey, i.e. the goal area, have not been taken into account in this 


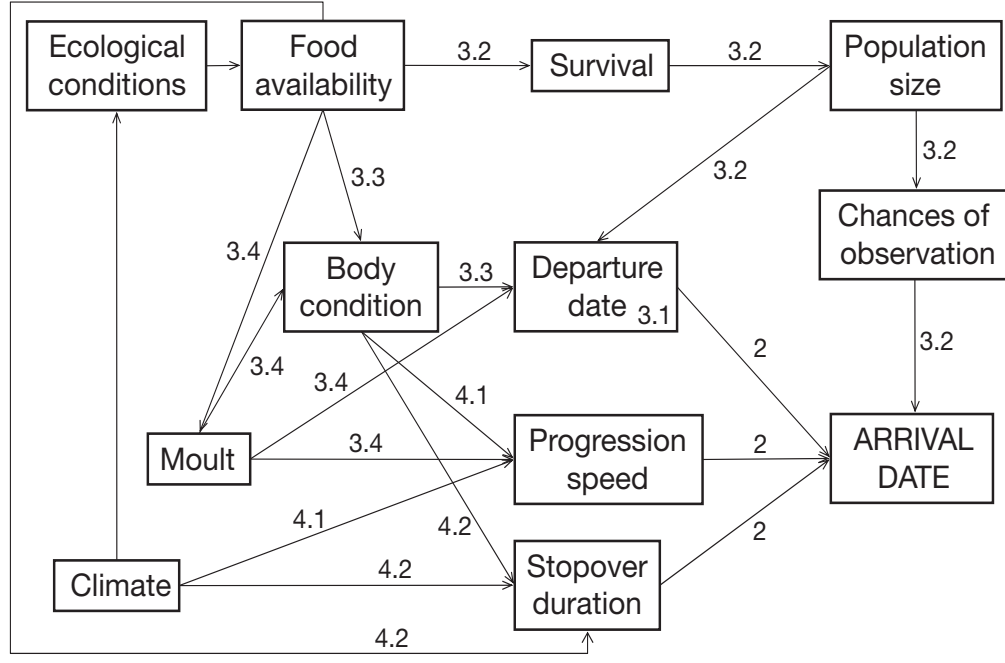

Fig. 3. Potential impacts of climate on the arrival date of a migratory bird species. This would be valid both for spring and autumn migration. In the latter case, breeding phenology should be included. Numbers indicate text sections for further details

sketch of migration (Fig. 3). However, the overwhelming majority of studies included some kind of climatic variable from the same site where arrivals are recorded (Mason 1995, Loxton et al. 1998, Sokolov et al. 1998, Ahas 1999, Loxton \& Sparks 1999, Sparks \& Mason 2001, Sueur \& Triplet 2001, Barrett 2002, Tryjanowski et al. 2002, Dolenec 2003, Lane \& Pearman 2003, Ptaszyk et al. 2003, Murphy-Klassen et al. 2005, Askeyev et al. 2007, Sparks \& Tryjanowski 2007). Birds depart from sites at 100s or 1000s of kilometres away from their goal areas (e.g. their wintering grounds in the tropics), and, thus, it is unlikely that they can accurately assess the climatic conditions at their destination sites (e.g. breeding grounds in temperate latitudes). The high number of significant relationships reported between the arrival at a certain place and the climate there can be attributed to the strong spatial autocorrelation of climatic variables, especially temperatures (Huin \& Sparks 1998, Ahola et al. 2004, Mitrus et al. 2005, Murphy-Klassen et al. 2005, Zalakevicius et al. 2006, Sparks et al. 2007). For example, in the case of spring arrivals, warmer springs at the breeding site are also related to warmer springs in the nearby passage areas that are traversed by individuals during the preceding days. Weather is governed by large-scale atmospheric circulatory systems, which can influence areas of 100s of kilometres. Therefore, climatic conditions at the study site are a surrogate for climatic conditions in a broader surrounding area. Relationships between arrivals and local climate at the study site can consequently be interpreted as effects of climate on progression speed or time spent at stopovers during the previous days of the migratory journey.
The huge number of significant relationships reported between climatic variables and arrival dates reflect complex underlying mechanisms rather than a single cause-effect relationship between 1 response variable (i.e. arrival) and 1 predictor variable (i.e. climate; see Fig. 3). Indeed, climate is the ultimate cause of arrival date variability, but there are several non-exclusionary ways to mediate climatic effects on avian migratory phenology. These ways (arrows in Fig. 3) can be classified as direct or indirect effects. Direct effects refer to those direct impacts of weather on departure decisions, progression speed, or stopover duration. Indirect effects refer to the cascade of effects derived from changes in the ecological conditions driven by interannual climatic fluctuations. Harsh climatic conditions (e.g. drought in arid regions or low temperature during winter in temperate regions) are associated with poor and restrictive ecological conditions. If ecological conditions are poor and restrictive, food resources will be scarce, and this will have negative repercussions on the survival and physiology of individuals.

The sketch proposed in Fig. 3 would be valid for both the arrival at the breeding grounds as well as at the wintering grounds, although, in the latter case, the effects of breeding phenology over departure must be included (Ellegren 1990, Sokolov 2000, Bojarinova et al. 2002). Nevertheless, there is little empirical evidence on the arrival dates at the wintering grounds (Sparks \& Mason 2004, Gordo \& Sanz 2005), and climate impacts over these dates have rarely been assessed (Sparks \& Mason 2004, see also ShamounBaranes et al. 2006). For this reason, I will focus examples mainly on spring arrivals at breeding grounds.

Climatic impacts on departure phenology from both breeding and wintering grounds can be evaluated following Fig. 3. In fact, departure and arrival should be considered as the beginning and end, respectively, of the same phenomenon: migration. Therefore, a comprehensive search of the climatic mechanisms underlying arrival date variability must include an assessment of climatic effects on departures because departures are a key piece of the migratory puzzle. Unfortunately, there is little knowledge about departure dates from wintering grounds (Kok et al. 1991, Sparks \& Mason 2004, Gordo \& Sanz 2005) in comparison to their coupled arrivals at the breeding grounds. However, the opposite situation is found for autumn migration: many studies have analysed departures from breeding grounds, but few have assessed the arrivals at the wintering areas (Kok et al. 1991, Sparks \& Mason 2004, Gordo \& Sanz 2005). 


\section{EFFECTS OF CLIMATE AND WEATHER IN DEPARTURE AREAS}

This section will be focussed on the direct and indirect ways in which climate and weather affect the departure date from a certain area (i.e. all arrows and boxes between climate and departure date in Fig. 3). Since the final aim is to assess the effect of departure date on arrival date, and primarily the latter is available for the breeding grounds, most of this discussion will be focussed on spring pre-nuptial migration.

\subsection{Plasticity of migration onset}

Photoperiod is the most reliable calendar, and for this reason birds use it to trigger their migration (Berthold 1996, Gwinner 1996). However, environmental conditions encountered by individuals in departure areas are different each year at the same date (i.e. interannual variability), and, consequently, they should be flexible in their responses (i.e. departure dates) in order to make the best decision. The evidence about internal clocks and the relevance of photoperiod as a trigger of migration are irrefutable (Berthold 1996). Nevertheless, such evidence has been obtained only for a few songbird species and under captive conditions. These experimental conditions are far from the complex situation found by migrant birds in the wild. In nature, individuals must evaluate many other environmental cues (e.g. weather, food supplies) before choosing a well-balanced response. For example, autumn departure dates can show large differences from year to year related to weather, which suggests a fine tuning of endogenous rhythms according to the particular environmental conditions (see Shamoun-Baranes et al. 2006). Furthermore, interannual climatic fluctuations could indirectly affect departure decisions of individuals due to food supplies (Fig. 3), which affect individuals' physiological status (Bairlein 1985, Biebach 1985, Biebach et al. 1986, Gwinner et al. 1988). Endogenous rhythms would trigger migratory restlessness, but migratory onset should not be effective until the individual's body condition is sufficiently prepared. Leaner individuals would delay departure to obtain all the necessary fuel reserves to ensure their survival during migratory flight. Therefore, the potential effect of climate at wintering grounds on migratory onset through ecological conditions and food availability should be taken into account (Studds \& Marra 2007, this issue).

Recent studies have reported evidence in favour of a certain phenotypic plasticity in migratory phenology, in response to variable ecological conditions in the wintering quarters. The arrival date of barn swallows Hirundo rustica in northern Italy between 1993 and
2001 was earlier after winters with favourable ecological conditions in their African wintering grounds, as was reflected by higher values of the normalized difference vegetation index (NDVI; Saino et al. 2004b). Interestingly, this effect was only detected in old individuals (i.e. individuals of 2 or more years). The arrival of $1 \mathrm{yr}$ old individuals was not related to wintering conditions, due to the time taken to choose a colony in their first breeding season, which is independent of conditions in Africa. In turn, arrival dates had an effect on breeding success, and, consequently, ecological conditions during winter showed an indirect effect on individuals' fitness (see also Dallinga \& Schoenmakers 1987, Marra et al. 1998, Hötker 2002, Norris et al. 2004a). In a locality from north-eastern Spain, 6 common trans-Saharan bird species delayed their arrival dates between 1953 and 2004 (Gordo et al. 2005). This delay was unexpected, since all spring phenological events (e.g. leaf unfolding, flowering and insect appearance) were advanced (Peñuelas et al. 2002). In 5 out of 6 species, rainy years in Africa, especially in the Sahel region, were linked to an earlier arrival. Since precipitation has decreased in that region, as a result of the persistent droughts during the last decades (Zeng 2003, Dai et al. 2004), individuals arrive later in response to impaired ecological conditions there. Results for this single population have been confirmed in 100s of localities spread throughout Spain for several species (Gordo \& Sanz 2006a). In the case of the barn swallow, the effect of conditions in wintering grounds was even greater than that of Spanish temperatures (Fig. 4). Dallinga \& Schoenmakers (1987) drew similar conclusions from the negative relationship between white stork Ciconia ciconia arrivals in Alsace (France) and the discharge of the Niger and Senegal Rivers dur-

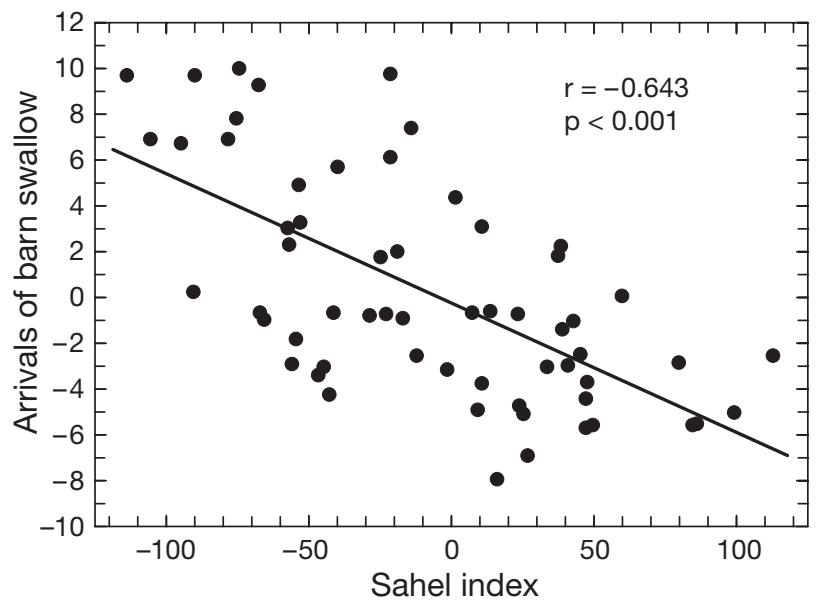

Fig. 4. Hirundo rustica. Effect of the Sahel index during the rainy season on barn swallow arrivals in Spain in the following spring. Annual arrival of barn swallows is the annual average of resids of first arrival dates from a model to account for spatial variability (see Gordo \& Sanz 2006a for more details) 
ing the preceding rainy season. Flows of these rivers are a good proxy for the amount of rainfall in the Sahel region (the wintering region of western white storks; Fiedler 2001) and, thus, of the ecological conditions there. In an arid region, such as the Sahel, wet years are benign years, while dry years are restrictive. Forchhammer et al. (2002) found a negative relationship between the NAO index and the arrival of 2 longdistance migrants, the cuckoo Cuculus canorus and the barn swallow Hirundo rustica, to Norway. Since high NAO values are related to increased vegetation productivity in southern Africa (the wintering quarter of these populations), the authors suggest that improved foraging conditions would allow individuals to depart earlier from Africa as a result of an improved body condition.

\subsection{Population numbers}

Food availability could affect departure date in 2 non-exclusionary ways, which can be designated longand short-term effects (Fig. 3). The long-term effects refer to the ecological conditions during the period that individuals remain in a certain area. Such ecological conditions can affect population numbers through survival. Poor ecological conditions can increase both inter- and intraspecific competition for resources and, consequently, increase the mortality risk due to starvation. A large number of studies have demonstrated the connection between poor environmental conditions in wintering grounds and the low survival rates of individuals in the following breeding season (Winstanley et al. 1974, Den Held 1981, Cavé 1983, Svensson 1985, Dallinga \& Schoenmakers 1987, Kanyamibwa et al. 1990, Peach et al. 1991, Marchant 1992, Kanyamibwa et al. 1993, Møller 1994, Szép 1995, Barbraud et al. 1999, Foppen et al. 1999, Sillett et al. 2000, Boano et al. 2004, Newton 2004, Sæther et al. 2006). Population size can directly affect the recorded arrival date through a methodological artefact. Migrant individuals can be recorded earlier in larger populations simply due to the increased opportunities to detect an individual. This kind of bias would be especially probable when arrival dates of populations are quantified by the individuals that arrive first (Tryjanowski et al. 2005). Tryjanowski \& Sparks (2001) showed for a red-backed shrike Lanius collurio population from western Poland that the advancement of the arrival date during the period from 1983 to 2000 was related to the increase of the studied breeding population. The authors proposed 2 potential factors acting simultaneously: (1) the higher probability of observing an early individual in a larger population and (2) the increased singing activity in denser populations. Similar effects of population size over arrivals have been found for the turtle dove Streptopelia decaocto (Sparks 1999, but see Browne \& Aebischer 2003), the nightingale Luscinia megarhynchos (Huin \& Sparks 2000), the blackcap (Sparks et al. 2001) and many other migrants (Croxton et al. 2006, Sparks et al. 2007) from Britain. This bias due to population size could be especially serious for those more cryptic and skulking species for which chances of observation are even more strongly constrained by species behaviour. Unfortunately, population number trends are rarely available to test this potential effect.

Wintering population size could also directly affect departure date from wintering grounds through competitiveness among males for an early return in protandry species (Morbey \& Ydenberg 2001). It could be predicted that competition for a breeding territory, as well as sexual selection, become more marked the higher the number of males (e.g. due to high wintering survival; Kokko 1999, Møller 2004, Coppack et al. 2006, Kokko et al. 2006, Jonzén et al. 2007a, Møller 2007, Rainio et al. 2007, this issue). Since important features for individual fitness, such as mate quality, resource availability during breeding season, or the number of offspring, rely largely on the acquisition of breeding territory and its characteristics, selection pressures over this parameter should be very strong and will be stronger as competition increases for territory acquisition. On the other hand, Spottiswoode et al. (2006) demonstrated that those species under the strongest sexual selection show the steepest advancement in their arrival dates (but see Rainio et al. 2007). Therefore, the mating system could also help to explain the variability in the adaptive responses of migratory bird species to climate change, since stronger responses should be expected in those species under stronger sexual selection.

\subsection{Physiological condition}

The short-term climatic effect refers to the hypothetical effect of food availability on individual body condition in departure areas during the days or weeks preceding migration onset (Fig. 3). Individuals undergo surprising behavioural and physiological changes before migration (Berthold 1996). The time required for the acquisition of the necessary pre-migratory body condition (i.e. fuel stores) will depend on the foraging opportunities offered by the occupied habitat as well as the foraging abilities of each individual. In an environment with scarce food supply, individuals will need more time to store the necessary fuel reserves to guarantee the onset of the migratory journey. Marra et al. (1998) demonstrated that winter habitat may be limiting for breeding success and fitness of migrants (see 
also Sherry \& Holmes 1996, Norris et al. 2004a). Individuals' migratory schedule and physiological status in the American redstart Setophaga ruticilla was determined by the habitat occupied during the winter (Studds \& Marra 2007). In the Jamaican wintering grounds, those individuals from scrub habitat (i.e. poor environment) showed several deteriorating physical features (e.g. loss of body mass during winter, elevated plasma corticosterone; see also Marra \& Holberton 1998) and departed significantly later than those individuals from forest habitat (i.e. rich environment). In the breeding grounds of central New Hampshire (USA), individuals that arrived earlier showed isotopic signatures related to wetter tropical habitats (i.e. rich), which suggests that earlier individuals occupy better wintering habitats. Similar conclusions were obtained for individuals on passage through the Caribbean of another neotropical migrant species, the black-throated blue warbler Dendroica caerulescens (Bearhop et al. 2004). Those migrant individuals with better body condition showed isotopic signatures belonging to moist forest habitats, i.e. good habitats. However, those individuals overwintering in poor, xeric environments returned to the breeding grounds in poorer physical condition, which could be detrimental to their fitness by means of later arrivals and increased risk of mortality during migration. In Iceland, the arrival date of individuals of the black-tailed godwit Limosa limosa islandica was strongly dependent on the population trend detected at the site selected to overwinter (Gill et al. 2001). Those individuals from increasing wintering populations arrive later than those from stable populations, because food intake rates previous to migration were lower in the increasing populations. A later arrival date has negative impacts on breeding success, because late individuals are relegated to lower quality territories (Gunnarsson et al. 2005, 2006).

\subsection{Moult}

Food availability in departure areas could have indirect effects on arrival dates through moulting (Fig. 3). Birds replace their feathers during moult, a costly process (Dietz et al. 1992, Schieltz \& Murphy 1995, Portugal et al. 2007) that takes place before pre- and postnuptial migration. Moult can be affected by resource availability, which, in turn, depends on climatic variability (Fig. 3). Van den Brink et al. (2000) showed that the rate of primary and tail moult in barn swallows was closely related to environmental conditions encountered by this species in their African wintering grounds. The rate of moult was higher in those years with higher amounts of rainfall during winter. Wet years were associated with a greater abundance of insects and, by implication, to an improvement in foraging conditions of insectivorous birds, such as barn swallows. Furthermore, in this species, the availability of roosting habitat (i.e. reedbeds), which depends on river discharge (which, in turn, depends on rainfall), affects the density of individuals and the distance to reach the foraging areas. In dry years, roosting habitat is scarce, and barn swallows are forced to concentrate in a few places. This fact implies a higher competition for aerial insects and a necessity to move further to forage.

Moult can affect migratory phenology through: (1) time constraints and (2) quality of replaced feathers. Time constraints refer to potential delay of departure until the moult is complete. Due to the costs of moult (Dietz et al. 1992, Schieltz \& Murphy 1995, Portugal et al. 2007), individuals avoid overlapping this process with breeding (Hemborg et al. 1998, Hall \& Fransson 2000, Morales et al. 2007) or migration (Gorney \& Yom-Tov 2001, PérezTris et al. 2001, Norris et al. 2004b). However, this is not always possible. At high latitudes, summer is too short and imposes a trade-off on the time allocation for breeding, moult and preparation for autumn migration (Hemborg et al. 1998, 2001). Late individuals in the breeding season are also affected by this trade-off (Svensson \& Nilsson 1997, Hall \& Fransson 2000). Nevertheless, time constraints can be dealt with by overlapping moult and breeding (Underhill et al. 1992, Svensson \& Nilsson 1997, Hemborg et al. 1998, 2001), accelerating feather growth (Hall \& Fransson 2000), suppressing moult before migration onset (Hall \& Fransson 2001), or overlapping moult and migration (Norris et al. 2004b). Therefore, individuals have mechanisms to avoid the time constraints that moult imposes on autumn departure date. In the case of pre-nuptial moult, individuals are relatively free of time constraints, and it may be for this reason that replacement of the same feathers takes more time in the pre-nuptial moult in some species (Underhill et al. 1992).

The quality of replaced feathers depends on the moult rate (Dawson et al. 2000) and food availability (Van den Brink et al. 2000, Saino et al. 2004a; but see Salewski et al. 2004). The quality of feathers affects the manoeuvrability and flying performance of individuals (Swaddle et al. 1996, Gorney \& Yom-Tov 2001), as well as the resistance to abrasion, thermoregulatory capacity and coloration (Serra et al. 2007). In aerial feeders, like the barn swallow, this could have serious repercussions on its foraging ability and thus on body condition (Fig. 3; Pérez-Tris et al. 2001, Rubolini et al. 2002).

Moreover, consequences of moult through phenology can go beyond the level of individual success. When feathers constitute a sexual character, they undergo strong selective pressures. Saino et al. (2004a) demonstrated that the length of the tail ornament in barn swallow males from northern Italy was longer after winters with good ecological conditions in Africa. 
Since male sexual attractiveness depends on tail ornaments (Møller 1988), ecological conditions in wintering quarters affect an individual's fitness through sexual selection during the following breeding season. In species with sexual selection, the sex under selection must develop high-quality ornaments to attract mates. When feathers are a sexual trait, the development of such traits requires time (i.e. moulting period). The longer the moulting period, the better, potentially, the feather quality (Dawson et al. 2000, Hall \& Fransson 2000) and, consequently, the better the sexual character phenotype (Serra et al. 2007). Therefore, it is interesting to note the potential existence of a trade-off between moulting and departure time, which merits further attention (Saino et al. 2004a, Serra et al. 2007).

\section{EFFECTS OF CLIMATE AND WEATHER EN ROUTE}

\subsection{Progression speed}

En route, climatic effects can act on the progression speed as well as on the frequency and duration of the stopovers, both directly and indirectly (Fig. 3). In the case of progression speed, a direct effect would be the weather conditions during travel, which can reduce or increase the flying speed under unfavourable (e.g. rainfall) or favourable (e.g. tailwinds) conditions, respectively (reviewed in Richardson 1978, Richardson 1990; see also Bernis 1966, Alerstam 1990, Newton 2007). The median date of spring passage of the song thrush Turdus philomelos has advanced by $10 \mathrm{~d}$ during the last 4 decades in the south-eastern Baltic region (Sinelschikova \& Sokolov 2004). The main factor controlling the number of trapped song thrushes at the ringing station of Rybachy (SE Baltic) was the frequency and speed of tailwinds from France to the Baltic region during the spring (Sinelschikova et al. 2007). Interestingly, frequency and speed of tailwinds over central Europe have increased during the last 40 yr. Therefore, flight conditions have been improved. This fact has allowed an increase in the progression speed of song thrushes and, subsequently, an advancement of arrival dates. In Norway, arrivals of the song thrush, as well as the skylark Alauda arvensis and the starling Sturnus vulgaris (both short-distance migrants), were affected by the NAO (Forchhammer et al. 2002) - the higher the NAO, the earlier the arrival date. The effect of the NAO index would also be through wind and, consequently, progression speed en route, since high values of the NAO are related to favourable wind conditions for northward migration.

An individual's progression speed could also be affected indirectly by climate through body condition and quality of replaced feathers (see Sections 3.3 and
3.4). Lean individuals can better avoid predation (Lind et al. 1999, Kullberg et al. 2000, Cimprich \& Moore 2006), but a lighter body mass would be penalized with a shorter flight autonomy. Therefore, lean individuals must stop to replenish their fuel reserves more frequently (Bairlein 1985, Biebach 1985, Biebach et al. 1986, Yosef et al. 2006).

\subsection{Stopover frequency and duration}

Stopovers are key periods for migrant birds in spite of their short duration within the annual schedule. Indeed, success of the migratory journey depends greatly on what happens during stopover periods and at stopover sites (Newton 2006). The greater amount of time spent at stopovers, the greater the delay in the arrival date, with all else being equal. Climate can impact the number and duration of stopovers directly through en route weather conditions. Bad weather conditions can force individuals to land without physiological necessity (i.e. without empty fuel reserves) and to remain stopped until weather becomes suitable for flying (Zalakevicius 2001, Barriocanal et al. 2002, Gordo 2006). Weather conditions can also be important in take-off decisions. Nocturnal migrant passerines that stopped at Ottenby (Sweden) preferably resumed their migration on those days with tailwinds (Åkesson \& Hedenström 2000).

Climate can affect the time spent at a stopover through the ecological conditions imposed at the stopover site (Fig. 3). Refuelling opportunities can be determined by the amount of food supplies, which, in turn, depends on ecological conditions. Food supplies at stopover sites can vary greatly both inter- and intrannually. An example of the interannual variation effect is provided by rufous hummingbirds Selasphorus rufus during their autumn migration in North America (Russell et al. 1994). The density of nectarproviding flowers was low in dry years. During those years, the stopover duration of rufous hummingbirds in the Sierra Nevada (California, USA) was longer as a result of the impaired refuelling opportunities and low body mass of incoming birds. At temperate latitudes, interannual variability can also be due to the degree of phenological development of the ecological conditions at stopover sites. An advanced year as a result of a warmer spring can notably improve foraging opportunities, especially in insectivorous birds, because arthropod abundance is higher during dry and warm days, which could enhance feeding rates (Schaub \& Jenni 2001). Intrannual variation refers to changes in food supplies within the course of migration. Several studies have reported a depletion of resources by the first arriving migrants (Ottich \& Dierschke 2003). This 
fact imposes poor conditions for late migrants, which will spend more time in efforts to replenish their fuel reserves as a consequence of food scarcity (Russell et al. 1994, Nolet \& Drent 1998).

\subsection{Northern versus southern populations}

Ecological and weather conditions during the spring at northern latitudes have improved in recent decades thanks to recent climatic changes. Progression through these areas is faster due to increased flight speed as a consequence of more favourable weather (Sinelschikova et al. 2007) and reduced time spent at the stopover sites as a consequence of improved foraging conditions due to advanced spring phenology (e.g. Huin \& Sparks 1998). However, most of the studied populations were located at high (or very high) latitudes (Barrett 2002, Forchhammer et al. 2002, Gilyazov \& Sparks 2002, Vähätalo et al. 2004, Stervander et al. 2005, Rainio et al. 2006; see Fig. 1), where en route climate conditions have greater opportunities to impact migratory phenology in the later stages of migration through Europe or North America. For example, if we consider pre-nuptial migration of a widespread trans-Saharan migrant such as the barn swallow, a Scandinavian individual is just at the halfway point of its migratory journey when it reaches the breeding area of the Moroccan individuals (Southern 1938). Therefore, we should expect a greater impact of climate from temperate regions as we analyse arrival dates from northern populations. In this sense, the study of southern populations (Dolenec 2003, Gordo \& Sanz 2005, Gordo et al. 2005, Rodríguez-Teijeiro et al. 2005, Gordo \& Sanz 2006a, Rubolini et al. 2007a) becomes a good alternative to determine the relative importance of climatic changes in temperate passage regions versus climatic changes in departure areas on migratory phenology of populations from northern latitudes.

\section{VARIABLES EMPLOYED TO ASSESS CLIMATE CHANGE EFFECTS ON MIGRATORY PHENOLOGY}

\subsection{A quantitative analysis of a difficult choice}

In facing the challenge of the assessment of climate change effects on avian migratory phenology, the first pitfall is the plethora of variables that quantify climatic fluctuations. Climatologists have developed a huge number of variables to quantify the complexities of the atmosphere, but which variables should ecologists select? In general, climate variables show a strong collinearity because they summarize the same phenomenon: weather. Weather results from a complex and unique combination of physical atmospheric features at a certain time and place. Nevertheless, all of these features always covary in the same way. A simple example: temperature is usually lower when it is raining. Therefore, it is not surprising to find significant relationships between a single time series of arrival dates and several climatic variables. All of these relationships indicate the same thing: arrivals are affected by climate and are earlier (or later) under certain weather conditions. Therefore, large numbers of climatic explanatory variables, which are usually characterized by their high collinearity, should be summarized by applying multivariate techniques, such as principal component analysis or partial least squares regression (Gordo et al. 2005, Saino et al. 2007). Climatic indices, such as the NAO, are also a good summary of weather conditions in a single value. Multiple regression would also be a preferable alternative to many simple correlations in order to account simultaneously for the effects of several explanatory variables, especially in those cases where the geographical and temporal identity of key climate variables is unknown. Furthermore, some kind of selection procedure of the best subset of explanatory variables in multiple regression models can help us to reveal the most relevant climatic variables for the analysed arrival dates.

An overview of the studies dealing with temporal shifts in arrival date reveals that temperature is by far the most often employed explanatory variable (Fig. 5a; see also Appendix 1). Indeed, the main mechanism suggested for the advancement of arrival dates is global warming (see Section 1). In a minority of studies, other meteorological variables, such as precipitation (Sparks \& Carey 1995, Huin \& Sparks 1998, 2000, Boyd 2003, Sokolov \& Kosarev 2003, Kaňuščák et al. 2004, Chambers 2005, Gordo et al. 2005, Gordo \& Sanz 2006a, Sokolov 2006, Zalakevicius et al. 2006, Beaumont et al. 2007, Rubolini et al. 2007a, Saino et al. 2007, Sinelschikova et al. 2007, Studds \& Marra 2007) or wind (Boyd 2003, Sinelschikova et al. 2007) have been assessed in addition to temperature. The use of wind has been almost anecdotal (Boyd 2003, Sinelschikova et al. 2007), in spite of the fact that it is traditionally recognized as one of the most important drivers of migratory progression (Richardson 1978, 1990; see also Ball 1983). Only Boyd (2003) assessed the effects of all 3 types of variables in the arrival dates of 4 migratory birds to Iceland during the 20th century. In fact, this is probably the study with the most comprehensive examination of potential climatic influences on arrival dates, since he also evaluated the effects of NAO, snowmelt date, atmospheric pressure at sea level and plant growth as other potential explanatory variables. Furthermore, he used variables from departure, passage and breeding areas. Interest- 

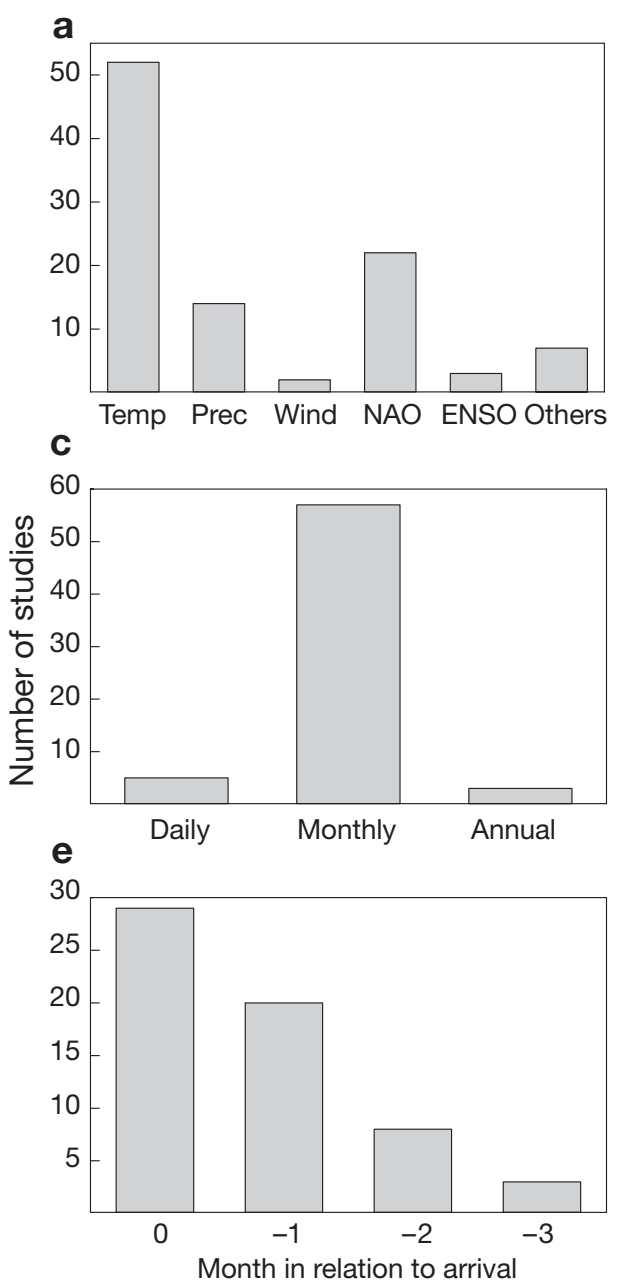

ingly, the only goal of some studies was the detection of temporal trends of bird arrivals (Wilson et al. 2000, Witt 2004, Mills 2005, Reichholf 2005, Tøttrup et al. 2006a), and thus the effect of climate in these time series remains to be assessed. In other studies, temporal trends of climatic variables were assessed, but there were no explicit relationships between phenological variables and climatic ones (Jenkins \& Watson 2000, Butler 2003, Gordo \& Sanz 2005, Beaumont et al. 2006).

Climatic indices, such as the NAO or El NiñoSouthern Oscillation (ENSO), have been used in a noteworthy number of studies (Fig. 5a). This is meaningful because climatic indices as explanatory variables of long-term trends in bird migratory phenology were applied for the first time only a few years ago (Forchhammer et al. 2002). Only 3 studies have evaluated the ENSO (Cotton 2003, Barbraud \& Weimerskirch 2006, MacMynowski \& Root 2007), in comparison to 22 that have used the NAO, due to the fact that the overwhelming majority of studies have been conducted in the Northern Hemisphere (see Fig. 1), where

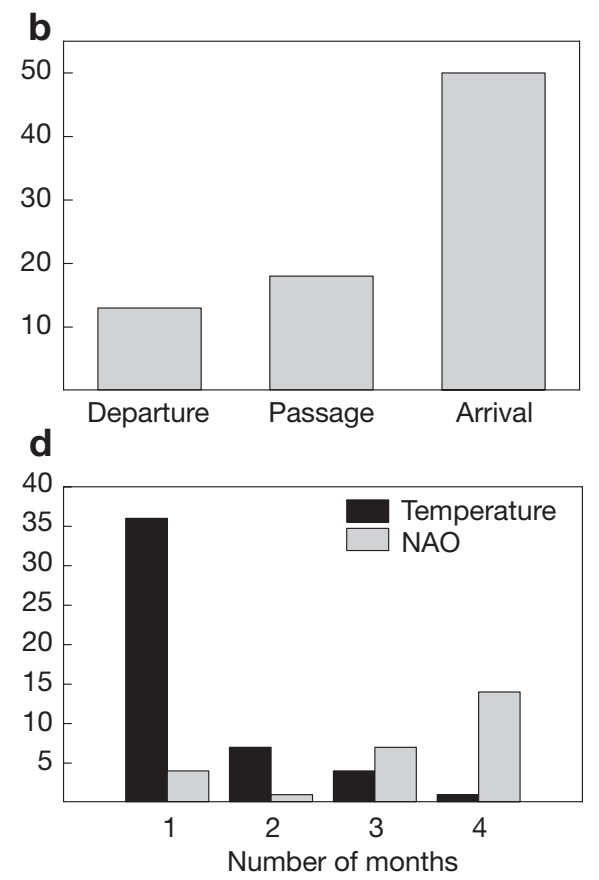

Fig. 5. Number of recent studies about long-term changes in bird migratory phenology and climate change that used: (a) temperature (Temp), precipitation (Prec), wind, North Atlantic Oscillation (NAO), El Niño-Southern Oscillation (ENSO), or other types of explanatory variables; (b) climatic variables from departure, passage and arrival areas (climate indices not included); (c) climatic variables with a daily, monthly, or annual temporal definition; (d) temperature and/or NAO according to the number of months during which both variables were defined; (e) monthly temperatures during the arrival month (0), 1 mo before $(-1), 2$ mo before $(-2)$, or 3 mo before $(-3)$

the NAO is probably the most important large-scale climate driver (Hurrell \& Van Loon 1997, Ottersen et al. 2001, Stenseth et al. 2003). Interestingly, none of the 3 studies found significant effects of the ENSO on arrival dates. The NAO has been evaluated in addition to other variables, such as temperature and precipitation, with only 8 studies exclusively using the NAO (Forchhammer et al. 2002, Hubálek 2003, 2004, Vähätalo et al. 2004, Stervander et al. 2005, Ahas \& Aasa 2006, Jonzén et al. 2006, Rainio et al. 2006). Only Barbraud \& Weimerskirch (2006) used another climatic index, the Southern Annular Mode, which did not have effects on the arrival of Antarctic birds.

Finally, I have found only 7 studies in which other types of variables have been used to assess the mechanisms underlying long-term trends in migratory phenology. These variables were related to atmospheric pressure (Boyd 2003, Zalakevicius et al. 2006), snow melting (Inouye et al. 2000, Boyd 2003), plant phenology (Boyd 2003, Marra et al. 2005, Sokolov 2006), vegetation productivity (Saino et al. 2004b) and sea ice extent (Barbraud \& Weimerskirch 2006). 
In summary, the assessment of climate on bird arrivals is strongly focussed on temperatures and the NAO (e.g. Gienapp et al. 2007). One reason for this prevalence could be the availability and ease of interpretation of both variables. Another non-exclusionary reason could be the geographical location of the study sites (see Fig. 1). Most of the studies have been conducted at northern latitudes, especially in the Atlantic and Baltic regions of Europe, where both temperature and the NAO are very important drivers for ecosystem functioning. More research is urgently needed in populations from southern latitudes, as well as studies employing several types of climatic explanatory variables (Boyd 2003, Kaňuščák et al. 2004, Sokolov 2006, Zalakevicius et al. 2006).

\subsection{Temperature}

High values of temperature in tropical departure areas can be linked to an impairment of ecological conditions as a result of an increase in aridity. However, high temperatures are linked to advancement of spring course (Menzel et al. 2006) and improved weather for progression (Zalakevicius et al. 2006) at temperate latitudes. Therefore, global warming could have the opposite effect on arrival dates, depending on the area considered: in tropical arid areas, it could delay departure or progression (but see Saino et al. 2007), while, in temperate regions, global warming could favour faster passage.

Significant relationships between arrival dates and temperature at the study locality do indeed reflect the effect of temperatures in the previously traversed passage areas due to the strong spatial autocorrelation of temperature. Zalakevicius et al. (2006) related the first arrival date of 40 species in areas around Vilnius (Lithuania) between 1971 and 2004 with temperature records from several European and North African cities. The overwhelming majority of species affected by temperatures showed simultaneously significant relationships with several cities. Does this mean that migrant individuals pass through all of them? No, it does not. This trend is simply due to the fact that temperature patterns from closely situated cities are quite similar (i.e. strong spatial autocorrelation). Hüppop \& Winkel (2006) related the arrival of several central European populations of pied flycatchers and temperature patterns throughout Europe. They found significant correlations between arrivals and many of the $2.5^{\circ} \times 2.5^{\circ}$ European grids. This massive effect of temperature is due simply to the climatic resemblance between neighbouring grids, because they are under a common pattern of climatic variability. Sparks et al. (2007) showed that the arrival of 10 common species to
6 different areas of the United Kingdom was related to March temperatures in both England and Spain. However, temperatures in both places had quite similar interannual variations $(\mathrm{r}=0.76)$.

Temperatures also suffer from temporal autocorrelation (i.e. temperatures between 2 consecutive moments are not fully independent). This would explain why species phenology is usually affected by several months (Loxton et al. 1998, Sokolov et al. 1998, 1999, Loxton \& Sparks 1999, Sokolov 2000, Tryjanowski et al. 2002, Sokolov \& Kosarev 2003, Zalakevicius et al. 2006, Croxton et al. 2006, Sparks et al. 2007). Does this mean that migrant individuals are migrating over the period of several months? No, it does not. This is simply because interannual fluctuations in temperatures for 2 consecutive months are usually similar. Ahola et al. (2004) studied the effect of climate along the migratory route and at the breeding grounds in the migration and breeding dates of pied flycatchers from south-western Finland for the period from 1970 to 2002. According to ringing recoveries, they selected 8 European cities along the migratory route and calculated mean temperatures during a time window of $3 \mathrm{wk}$. The authors made an accurate selection of the key period of temperatures for arrivals (i.e. highest correlation) by moving this time window in $3 \mathrm{~d}$ steps from 1 March onwards. Consecutive time windows showed very similar correlation coefficients with arrival dates of pied flycatchers. This similarity was maintained even between time windows with few overlapped days. This study stresses the strong temporal autocorrelation of temperatures and the necessity of an accurate selection of the time window of the climatic variables.

\subsection{Precipitation}

The direct and immediate effect of rainfall is to hinder individuals' flight and force them to land even when precipitation is scarce (Bernis 1966, Richardson 1978, 1990, Gordo 2006, Newton 2007). Therefore, rainfall slows migratory progression and could delay arrival date. Precipitation can also impact migratory phenology through indirect effects on ecological conditions (Fig. 3). In arid regions (e.g. the Sahel or Mediterranean region), a higher amount of rainfall improves ecological conditions, since water is a restrictive element for ecosystem productivity (VicenteSerrano \& Heredia-Laclaustra 2004, Herrmann et al. 2005). Nevertheless, ecosystem response to rainfall is not immediate (i.e. plants need time to grow). Time is also needed before primary production leads to an increase in arthropod populations. Furthermore, ecosystem response can be maintained even well after the occurrence of rainfall, e.g. by means of soil moisture. 
Hence, lag effects could be especially relevant in the study of this variable.

One interesting feature of precipitation is the latitudinal change in its ecological significance. Birds coming from the equator must face a minimum rainfall gradient around the tropics (Jones 1995, Salewski \& Jones 2006). As a result, rainfall becomes crucial in tropical environments, especially those that are more arid such as the African Sahel, where the alternation of dry and wet seasons is the most important determinant of intrannual variations in ecological conditions (Herrmann et al. 2005). However, it can become a nuisance for progression at northern latitudes where water is not a restrictive element.

\subsection{North Atlantic Oscillation}

Climatic indices, such as the NAO or ENSO, have received much attention due to their ability to assess general climatic conditions over large areas (Holmgren et al. 2001, Ottersen et al. 2001, Blenckner \& Hillebrand 2002, Hallett et al. 2002, Stenseth et al. 2003, Forchhammer \& Post 2004, Stenseth \& Mysterud 2005). Indeed, they avoid redundancy and spatial autocorrelation of meteorological variables because they summarize climatic conditions into a single value.

Many studies have shown that migrants advance their spring arrivals after winters with a positive phase of the NAO (Forchhammer et al. 2002, Boyd 2003, Hubálek 2003, 2004, Hüppop \& Hüppop 2003, Sokolov \& Kosarev 2003, Ahola et al. 2004, Kaňuščák et al. 2004, Vähätalo et al. 2004, Sparks et al. 2005, Stervander et al. 2005, Ahas \& Aasa 2006, Gunnarsson et al. 2006, Jonzén et al. 2006, Rainio et al. 2006, Zalakevicius et al. 2006, MacMynowski \& Root 2007; see a meta-analysis in Gienapp et al. 2007). Positive values of the NAO are linked to increased temperatures and precipitation in northern Europe and south-eastern North America and dry anomalies in the Mediterranean basin (Hurrell 1995, Hurrell \& Van Loon 1997). Therefore, a positive NAO index means ecologically improved conditions at northern latitudes, such as in central and northern Europe, as a result of advanced spring phenology (Aasa et al. 2004, Menzel et al. 2005). Migratory birds would progress quickly through European areas during those years with a positive NAO and would consequently arrive at their destinations earlier. Furthermore, a positive NAO is also associated with westerly and southerly tailwinds in western Europe, which favours northward flight of migrants (Forchhammer et al. 2002, Zalakevicius et al. 2006, Sinelschikova et al. 2007). Therefore, the advance of arrival dates observed during recent decades could be due to the prevalence of the positive mode of the NAO from
1980 onwards, especially during the winter (Visbeck et al. 2001, Osborn 2006).

In the case of North American migrants, only 2 studies have assessed the effects of the NAO on migration dates (Marra et al. 2005, MacMynowski \& Root 2007). Marra et al. (2005) found few relationships between the NAO and migration dates at both the Powdermill ringing station (Pennsylvania, USA) and the Long Point Bird Observatory (Ontario, Canada). However, MacMynowski \& Root (2007) found that the early phase of migration of $73 \%$ of long-distance migrants and $18 \%$ of short-distance migrants had a significantly negative correlation $(p<0.1)$ with NAO values at McCormick (near Chicago, USA). Nonetheless, more studies are necessary in order to draw conclusions about the effect of the NAO on American migrants.

\subsection{Normalized difference vegetation index}

At present, new analytical techniques offer possibilities to indirectly explore ecology of migratory birds (Pettorelli et al. 2005, Szép \& Møller 2005). Satellites of the U.S. National Oceanic and Atmosphere Administration (NOAA) have been measuring the daily reflected radiation of the earth's surface since 1981. Based on this collection of satellite data, anyone can obtain a value of the amount and vigour of vegetation on any land surface of the globe, expressed as the normalized difference vegetation index (NDVI), which relates reflected wave-lengths to the level of photosynthetic activity (Nicholson et al. 1998).

Satellite measurements are especially suitable for isolated and sparsely populated areas, such as most tropical wintering quarters of migratory birds, where ground climatic measures are scarce or even nonexistent. Another advantage of the NDVI is the fact that precise knowledge about the functioning of ecosystems is unnecessary. High values of NDVI are related to higher photosynthetic activity and, consequently, primary productivity (Nicholson et al. 1998, Nemani et al. 2003, Vicente-Serrano \& Heredia-Laclaustra 2004, Herrmann et al. 2005). Higher primary productivity can, in turn, increase food abundance in higher trophic levels, such as arthropods, the main food supply for most migratory birds. Therefore, high NDVI values will be related to improved ecological conditions and this can be related to earlier arrival (Fig. 3; see also previous sections). Unfortunately, NDVI data have only been available since 1981, which constrains the analysis of time series over a longer time span or ending before this decade.

Recent studies have demonstrated the huge potential of remote sensing to assess the effect of ecological conditions in wintering areas on biological features, 
such as arrivals, sexual selection and reproductive success of migratory birds (Saino et al. 2004a,b, Møller 2004, Møller \& Merilä 2004, Møller \& Szép 2005). Szép et al. (2006) employed NDVI data to predict wintering areas of Danish barn swallows on the basis of survival rate observed at the breeding grounds. Wintering mortality of the studied population was strongly related to NDVI values in some areas in South Africa. Authors suggest using this result as a guide to focus ringing efforts on concrete areas of wintering grounds. Both et al. (2006) showed that NDVI in wintering (western Africa) and passage (northern Africa) areas have effects on the laying phenology of the pied flycatcher. Nevertheless, the effect of NDVI in Africa was only significant for early European populations. These populations advanced their laying dates in those years with more vegetation productivity in Africa, maybe as a result of an earlier migratory onset and faster progression.

Nevertheless, there are still few studies that have employed remote sensing, and only two have related arrival dates to NDVI (Saino et al. 2004b, Gordo \& Sanz 2008). Furthermore, most studies are focussed on a few Danish and Italian populations of a single species (the barn swallow). Hence, further studies would be necessary to generalize the usefulness of the NDVI.

\section{SPATIAL AND TEMPORAL DEFINITIONS OF PREDICTORS TO ASSESS CLIMATIC EFFECTS}

\subsection{Quantitative analysis according to spatial criterion}

Explanatory variables used for the assessment of climate change impacts over bird migratory phenology can be classified in 3 groups according to their geographical origin: variables from departure area, variables from passage areas and variables from the arrival area. As shown in Fig. 5b, I have quantified the number of occurrences, i.e. the number of studies, for each geographical origin (see also Appendix 1). I have only considered studies dealing with spring arrivals, and I have not included climatic indices because of their large-scale influence. Variables from the arrival area (i.e. breeding grounds) are by far the most frequently employed. Moreover, they have been the only type of explanatory variable employed in 29 out of 46 studies that use variables from the arrival area. However, the effects found for climate from arrival area would be better attributed to climate from passage areas (see Section 4.3). This would be especially valid for those studies that used regional instead of local data from the study area (Marra et al. 2005, Hüppop \& Winkel 2006, MacMynowski \& Root 2007). MacMynowski \& Root (2007) used monthly temperatures calculated for a $5^{\circ} \times 5^{\circ}$ grid, because they considered local temperatures to be too strongly influenced by Lake Michigan and unrepresentative of spring conditions at about $42^{\circ}$ latitude in North America.

The number of studies that have explicitly included variables from passage areas are few (Fig. 5b; Huin \& Sparks 1998, 2000, Boyd 2003, Sokolov \& Kosarev 2003, Strode 2003, Ahola et al. 2004, Both et al. 2005, Chambers 2005, Mitrus et al. 2005, Rodríguez-Teijeiro et al. 2005, Croxton et al. 2006, Hüppop \& Winkel 2006, Sokolov 2006, Zalakevicius et al. 2006, Sinelschikova et al. 2007, Sparks \& Tryjanowski 2007, Sparks et al. 2007, Weidinger \& Král 2007) and all of them also included variables from the arrival area. Few studies have used variables from the departure area (i.e. wintering grounds; Boyd 2003, Cotton 2003, Kaňuščák et al. 2004, Saino et al. 2004b, Gordo et al. 2005, Mitrus et al. 2005, Rodríguez-Teijeiro et al. 2005, Gordo \& Sanz 2006a, Sokolov 2006, Zalakevicius et al. 2006, Saino et al. 2007, Sinelschikova et al. 2007, Weidinger \& Král 2007). Most of them also included variables from passage and arrival areas (exception Saino et al. 2004b). In summary, there is a strong bias toward the use of climate from arrival areas, probably because these are the variables most easily available to researchers. More research is needed to clarify the true extent of the relevance of climate at departure and passage areas on arrival dates.

\subsection{Quantitative analysis according to temporal criteria}

According to the temporal interval during which climatic variables are measured, I have identified 3 categories: daily, monthly and annual. In the case of spring migration, the overwhelming majority of studies have used variables calculated over months (Fig. 5c). Within this category there are diverse criteria to select the best temporal interval according to the type of variable (Fig. 5d). If we focus on temperature, most studies examined temperature only during a 1 mo period, especially the month of bird arrivals (Fig. 5e). Only a few studies have averaged monthly temperatures over several months to evaluate conditions during a longer temporal interval (2 mo: Loxton et al. 1998, Loxton \& Sparks 1999, Ptaszyk et al. 2003, Ledneva et al. 2004, Gordo et al. 2005, Marra et al. 2005, Gordo \& Sanz 2006a; 3 mo: Sparks \& Mason 2001, Dolenec 2003, Beaumont et al. 2006; or 4 mo: Kaňuščák et al. 2004). However, in the case of the NAO, there is an opposite trend (i.e. most studies use NAO values averaged over several months; see Fig. 5d). Studies that used the NAO during 4 mo are those that used the winter NAO (from December to March). The winter NAO is an especially important measure for climatic and ecological conditions during 
the spring in the Northern Hemisphere (Ottersen et al. 2001, Stenseth et al. 2003). Only a few studies have evaluated the NAO for different periods and intervals (1 mo: Boyd 2003, Sokolov \& Kosarev 2003, Ahas \& Aasa 2006, MacMynowski \& Root 2007; 2 mo: Sokolov 2006; or 3 mo: Cotton 2003, Hubálek 2003, Sokolov \& Kosarev 2003, Hubálek 2004, Ahas \& Aasa 2006, Zalakevicius et al. 2006, Rubolini et al. 2007a).

Only a few studies have used climatic data on a daily basis (Hüppop \& Hüppop 2003, 2005, Strode 2003, Ahola et al. 2004, Hüppop \& Winkel 2006). Daily data are preferable to any other kind of temporal interval because they allow climate conditions to be defined during precise periods of biological relevance (Hüppop \& Hüppop 2003, 2005, Ahola et al. 2004).

Climatic conditions during a complete annual cycle have been reported in some studies (Sparks \& Carey 1995, Chambers 2005, Gordo et al. 2005). However, an entire year seems to be too long a period for migratory birds (Fig. 3), as they spend only part of the year in the same place.

In summary, there is a strong bias toward the use of variables within a monthly time frame, probably because variables are typically reported in climatic databases by monthly averages. However, the month is a temporal interval imposed by the human calendar, but without any biological relevance. More research with daily values averaged over periods designed ad hoc (e.g. Ahola et al. 2004) is needed for a precise assessment of sensitive periods. It can be concluded that the existence of a strong bias in the spatial and temporal definition of variables presents serious concerns about the reported magnitudes of climate over arrival dates.

\subsection{Problems with the spatial and temporal definition of variables}

The correct selection of the type of explanatory variables, as well as a precise definition of their geographical and temporal range, is essential for the correct assessment of climate impacts (Stenseth \& Mysterud 2005). It is expected that climate will affect individuals just during a certain time period in a certain place, i.e. birds become sensitive to particular meteorological conditions (Shamoun-Baranes et al. 2006). In the case of the spring migration, it is expected a priori that there will be an effect of climate in wintering and passage areas during wintering and passage times because these are sites where and moments when individuals can be affected. Unfortunately, in most species there is no precise knowledge about the wintering and passage areas used during migration or about the period for each population. This is especially evident in most
European long-distance migrants (Walther \& Rahbek 2002, Kaňuščák et al. 2004, Walther et al. 2004). Furthermore, some climatic variables can affect migrants through lag effects (e.g. precipitation or winter NAO), and, consequently, their effects could occur beyond wintering or passage dates.

Another added difficulty is the apparently low fidelity to the wintering grounds shown by many migratory species. In the case of the Palaearctic-African migratory system, recurrence of migratory species at African wintering grounds has been reported for only 60 species (Salewski et al. 2000a). This low fidelity at the species level is much lower at the individual level. Salewski et al. $(2000 \mathrm{a}, \mathrm{b})$ found that just 4 out of 16 ringed species in the Comoé National Park (Ivory Coast) recurred in successive winters in the same ringing area. Individual recurrence ranged from 1 to $40 \%$ within these 4 species. In fact, most migrant species in sub-Saharan Africa show itinerancy within the wintering areas (Moreau 1972, Jones 1995), in some cases even performing well-defined intra-African migrations during winter. Such movements would be promoted by the progression of the dry season and a subsequent decline in the available resources (Jones 1995). This could be the reason for the low repeatability detected in the arrival dates of individuals for some species (Potti 1998, Hötker 2002, Berthold et al. 2004; but see Battley 2006). Since individuals overwinter in different areas each year, they would be affected by different conditions (Berthold et al. 2004).

If we do not know the precise wintering location of the studied population or we are studying a species with low wintering ground fidelity, 2 alternative methods can be used. Gordo et al. (2005) applied a conservative approach and considered all wintering ranges defined for the species, since they did not know the precise wintering area for their studied populations. For those species with broader wintering distribution, wintering range was divided into several climatic subregions to avoid the potentially confounding effect of the different intra- and interannual patterns of climatic variability. This approximation could also be useful to determine wintering areas. If we assume that interannual variability of arrival dates can be partially due to the variability in the departure date (Fig. 3, see Section 3.1), then those wintering areas with the strongest relationship to climatic patterns would be potential wintering area for the species (Rodríguez-Teijeiro et al. 2005, see also Szép et al. 2006). The same argument could be applied to determine the most important passage areas through the degree of association between arrivals and climatic patterns at those locations (Huin \& Sparks 1998, 2000, Sokolov \& Kosarev 2003, Ahola et al. 2004, Croxton et al. 2006, Hüppop \& Winkel 2006, Sokolov 2006, Zalakevicius et al. 2006). 
A second method would be the use of measures of arrival dates beyond 1 population (e.g. average for several populations; Gordo \& Sanz 2006a) or the first sighted individual (e.g. total distribution of arrivals; Knudsen et al. 2007, this issue). Such measures would summarize the interannual variability for a bulk of populations or individuals, which offers a much better suited measure of migratory phenology. Furthermore, since these measures are a summary of migratory behaviour of many individuals, they would be more comparable to regional climatic measures (e.g. gridded or country data), because both variables would be working on a macroscale.

Acknowledgements. Three anonymous reviewers provided valuable comments that notably improved the first draft of this manuscript.

\section{LITERATURE CITED}

Aasa A, Jaagus J, Ahas R, Sepp M (2004) The influence of atmospheric circulation on plant phenological phases in central and eastern Europe. Int J Climatol 24:1551-1564

Ahas R (1999) Long-term phyto-, ornitho- and icthyophenological time-series analyses in Estonia. Int J Biometeorol 42:119-123

Ahas R, Aasa A (2006) The effects of climate change on the phenology of selected Estonian plant, bird and fish populations. Int J Biometeorol 51:17-26

Ahola M, Laaksonen T, Sippola K, Eeva T, Rainio K, Lehikoinen E (2004) Variation in climate warming along the migration route uncouples arrival and breeding dates. Glob Change Biol 10:1610-1617

Åkesson S, Hedenström A (2000) Wind selectivity of migratory flight departures in birds. Behav Ecol Sociobiol 47: 140-144

Alerstam T (1990) Bird migration. Cambridge University Press, Cambridge

Askeyev OV, Sparks TH, Askeyev IV, Tryjanowski P (2007) Is earlier spring migration of Tatarstan warblers expected under climate warming? Int J Biometeorol 51:459-463

Bairlein F (1985) Body weights and fat deposition of Palaearctic passerine migrants in the central Sahara. Oecologia 66: 141-146

Bairlein F, Winkel W (2001) Birds and climate change. In: Lozan JL, Graßl H, Hupfer P (eds) Climate of the 21st century: changes and risks. Scientific Facts, GEO, Hamburg, p 278-282

Ball T (1983) The migration of the geese as an indicator of climate change in the southern Hudson Bay region between 1715 and 1815. Clim Change 5:85-93

Barbraud C, Weimerskirch H (2006) Antarctic birds breed later in response to climate change. Proc Natl Acad Sci USA 103:6248-6251

Barbraud C, Barbraud JC, Barbraud M (1999) Population dynamics of the white stork Ciconia ciconia in western France. Ibis 141:469-479

Barrett RT (2002) The phenology of spring bird migration to north Norway. Bird Study 49:270-277

Barriocanal C, Montserrat D, Robson D (2002) Influences of wind flow on stopover decisions: the case of the reed warbler Acrocephalus scirpaceus in the western Mediterranean. Int J Biometeorol 46:192-196
Battley PF (2006) Consistent annual schedules in a migratory shorebird. Biol Lett 2:517-522

Bearhop S, Hilton GM, Votier SC, Waldron S (2004) Stable isotope ratios indicate that body condition in migrating passerines is influenced by winter habitat. Proc R Soc Lond B 271(Suppl):S215-S218

Bearhop S, Fiedler W, Furness RW, Votier SC and others (2005) Assortative mating as a mechanism for rapid evolution of a migratory divide. Science 310:502-504

Beaumont LJ, McAllan IAW, Hughes L (2006) A matter of timing: changes in the first date of arrival and last date of departure of Australian migratory birds. Glob Change Biol 12:1339-1354

Bernis F (1966) Migración de aves. Tratado teórico y práctico. SEO, Madrid

Berthold P (1996) Control of bird migration. Chapman \& Hall, London

Berthold P, Kaatz M, Querner U (2004) Long-term satellite tracking of white stork (Ciconia ciconia) migration: constancy versus variability. J Ornithol 145:356-359

Bezzel E, Jetz W (1995) Verschiebung der Wegzugperiode bei der Mönchsgrasmücke (Sylvia atricapilla) 1966-1993Reaktion auf die Klimaerwärmung. J Ornithol 136:83-87

Biebach H (1985) Sahara stopover in migratory flycatchers: fat and food affects the time program. Experientia 41: 695-697

Biebach H, Friedrich W, Heine G (1986) Interaction of body mass, fat, foraging and stopover period in trans-Saharan migrating passerine bird. Oecologia 69:370-379

Blenckner T, Hillebrand H (2002) North Atlantic Oscillation signatures in aquatic and terrestrial ecosystems - a metaanalysis. Glob Change Biol 8:203-212

Boano G, Bonardi A, Silvano F (2004) Nightingale Luscinia megarhynchos survival rates in relation to Sahel rainfall. Avocetta 28:77-85

Bojarinova JG, Rymkevich TA, Smirnov OP (2002) Timing of autumn migration of early and late-hatched great tits Parus major in NW Russia. Ardea 90:401-409

Both C (2007) Comment on 'Rapid advance of spring arrival dates in long-distance migratory birds'. Science 315:598b

Both C, te Marvelde L (2007) Climate change and timing of avian breeding and migration throughout Europe. Clim Res 35:93-105

Both C, Visser ME (2001) Adjustment to climate change is constrained by arrival date in a long-distance migrant bird. Nature 411:296-298

Both C, Bijlsma R, Visser ME (2005) Climatic effects on timing of spring migration and breeding in a long-distance migrant, the pied flycatcher Ficedula hypoleuca. J Avian Biol 36:368-373

Both C, Sanz JJ, Artemyev AV, Blaauw B and others (2006) Pied flycatchers Ficedula hypoleuca travelling from Africa to breed in Europe: differential effects of winter and migration conditions on breeding date. Ardea 94:511-525

Boyd H (2003) Spring arrival of passerine migrants in Iceland. Ringing Migr 21:193-201

Bradley NL, Leopold AC, Ross J, Huffaker W (1999) Phenological changes reflect climate change in Wisconsin. Proc Natl Acad Sci USA 96:9701-9704

Brown CR, Brown MB (2000) Weather-mediated natural selection on arrival time in cliff swallows (Petrochelidon pyrrhonota). Behav Ecol Sociobiol 47:339-345

Browne SJ, Aebischer NJ (2003) Temporal changes in the migration phenology of turtle doves Streptopelia turtur in Britain, based on sightings from coastal bird observatories. J Avian Biol 34:65-71

Butler CJ (2003) The disproportionate effect of global warm- 
ing on the arrival dates of short-distance migratory birds in North America. Ibis 145:484-495

Cavé AJ (1983) Purple heron survival and drought in tropical West Africa. Ardea 71:217-224

Chambers LE (2005) Migration dates at Eyre Bird Observatory: Links with climate change? Clim Res 29:157-165

Cimprich DA, Moore FR (2006) Fat affects predator-avoidance behavior in gray catbirds (Dumetella carolinensis) during migratory stopover. Auk 123:1069-1076

Coppack T, Both C (2002) Predicting life-cycle adaptation of migratory birds to global climate change. Ardea 90: 369-377

Coppack T, Pulido F (2004) Photoperiodic response and the adaptability of avian life cycles to environmental change. Adv Ecol Res 35:131-150

Coppack T, Pulido F, Czisch M, Auer DP, Berthold P (2003) Photoperiodic response may facilitate adaptation to climate change in long-distance migratory birds. Proc R Soc Lond B 270(Suppl):S43-S45

Coppack T, Tøttrup AP, Spottiswoode C (2006) Degree of protandry reflects level of extrapair paternity in migratory songbirds. J Ornithol 147:260-265

Cotton PA (2003) Avian migration phenology and global climate change. Proc Natl Acad Sci USA 100:12219-12222

Crick HQP (2004) The impact of climate change on birds. Ibis 146:48-56

Crick HQP, Sparks TH (2006) Changes in the phenology of breeding and migration in relation to global climate change. Acta Zool Sin 52:154-157

Croxton PJ, Sparks TH, Cade M, Loxton RG (2006) Trends and temperature effects in the arrival of spring migrants in Portland (United Kingdom) 1959-2005. Acta Ornithol 41: 103-111

Dai A, Lamb PJ, Trenberth KE, Hulme M, Jones PD, Xie PP (2004) The recent Sahel drought is real. Int J Climatol 24:1323-1331

Dallinga JH, Schoenmakers S (1987) Regional decrease in the number of white storks (Ciconia c. ciconia) in relation to food resources. Colon Waterbirds 10:167-177

Dawson A, Hinsley SA, Ferns PN, Bonser RHC, Eccleston L (2000) Rate of moult affects feather quality: a mechanism linking current reproductive effort to future survival. Proc R Soc Lond B 267:2093-2098

Den Held JJ (1981) Population changes in the purple heron in relation to drought in the wintering area. Ardea 69: 185-191

Dietz MW, Daan S, Masmad D (1992) Energy requirements for molt in the kestrel Falco tinnunculus. Physiol Zool 65: $1217-1235$

Dolenec Z (2003) First arrival dates of spring migrant passerines in Croatia. Isr J Zool 49:67-70

Dunn PO (2004) Breeding dates and reproductive performance. Adv Ecol Res 35:69-87

Easterling DR, Horton B, Jones PD, Peterson TC and others (1997) Maximum and minimum temperature trends for the globe. Science 277:364-367

Ellegren H (1990) Timing of autumn migration in bluethroats Luscinia svecica svecica depends on timing of breeding. Ornis Fenn 67:13-17

Fiedler W (2001) Large-scale ringing recovery analysis of European white storks (Ciconia ciconia). The Ring 23:73-79

Foppen R, ter Braak CJF, Verboom J, Reijnen R (1999) Dutch sedge warblers Acrocephalus schoenobaenus and WestAfrican rainfall: empirical data and simulation modelling show low population resilience in fragmented marshlands. Ardea 87:113-127

Forchhammer MC, Post E (2004) Using large-scale climate indices in climate change ecology studies. Popul Ecol 46: $1-12$

Forchhammer MC, Post E, Stenseth NC (2002) North Atlantic Oscillation timing of long- and short-distance migration. J Anim Ecol 71:1002-1014

Forstmeier W (2002) Benefits of early arrival at breeding grounds vary between males. J Anim Ecol 71:1-9

Gatter W (1992) Zugzeiten und Zugmuster im Herbst: Einfluß des Treibhauseffekts auf den Vogelzug? J Ornithol 133: 427-436

Gienapp P, Leimu R, Merilä J (2007) Responses to climate change in avian migration time-microevolution versus phenotypic plasticity. Clim Res 35:25-35

Gill JA, Norris K, Potts PM, Gunnarsson TG, Atkinson PW, Sutherland WJ (2001) The buffer effect and large-scale population regulation in migratory birds. Nature 412: $436-438$

Gilyazov A, Sparks T (2002) Change in the timing of migration of common birds at the Lapland Nature Reserve (Kola Peninsula, Russia) during 1931-1999. Avian Ecol Behav 8: $35-47$

Gordo O (2006) Unusual pre-roosting behaviour of barn swallows Hirundo rustica during autumn migration. Revista Catalana d'Ornitologia 22:40-42

Gordo O, Sanz JJ (2005) Phenology and climate change: a long-term study in a Mediterranean locality. Oecologia 146:484-495

Gordo O, Sanz JJ (2006a) Climate change and bird phenology: a long-term study in the Iberian Peninsula. Glob Change Biol 12:1993-2004

Gordo O, Sanz JJ (2006b) Temporal trends in phenology of the honey bee Apis mellifera (L.) and the small white Pieris rapae (L.) in the Iberian Peninsula (1952-2004). Ecol Entomol 31:261-268

Gordo O, Sanz JJ (2008) The relative importance of conditions in wintering and passage areas on spring arrival dates: the case of long-distance Iberian migrants. J Ornithol (in press), doi: 10.1007/s10336-007-0260-z

Gordo O, Brotons L, Ferrer X, Comas P (2005) Do changes in climate patterns in wintering areas affect the timing of the spring arrival of trans-Saharan migrant birds? Glob Change Biol 11:12-21

Gorney E, Yom-Tov Y (2001) Molt during spring migration: a comparison of four species of raptors. J Field Ornithol 72: 96-105

Gunnarsson TG, Gill JA, Newton J, Potts PM, Sutherland WJ (2005) Seasonal matching of habitat quality and fitness in a migratory bird. Proc R Soc Lond B 272:2319-2323

Gunnarsson TG, Gill JA, Atkinson PW, Gélinaud G and others (2006) Population-scale drivers of individual arrival times in migratory birds. J Anim Ecol 75:1119-1127

Gwinner E (1996) Circadian and circannual programmes in avian migration. J Exp Biol 199:39-48

Gwinner E, Schwalb H, Schwalb-Benzinger L (1988) Effects of food-deprivation on migratory restlessness and diurnal activity in the garden warbler Sylvia borin. Oecologia 77: 321-326

Hall KSS, Fransson T (2000) Lesser whitethroats under timeconstraint moult more rapidly and grow shorter wing feathers. J Avian Biol 31:583-587

Hall KSS, Fransson T (2001) Wing moult in relation to autumn migration in adult common whitethroats Sylvia communis communis. Ibis 143:580-586

Hallett TB, Coulson T, Pilkington JG, Clutton-Brock TH, Pemberton JM, Grenfell BT (2004) Why large-scale climate indices seem to predict ecological processes better than local weather. Nature 430:71-75 
Hemborg C, Lundberg A, Siikamäki P (1998) Trade-off between reproduction and moult - a comparison of three Fennoscandian pied flycatcher populations. Oecologia $117: 374-380$

Hemborg C, Sanz JJ, Lundberg A (2001) Effects of latitude on the trade-off between reproduction and moult: a longterm study with pied flycatcher. Oecologia 129:206-212

Herrmann SM, Anyamba A, Tucker CJ (2005) Recent trends in vegetation dynamics in the African Sahel and their relationship to climate. Glob Environ Change 15:394-404

Holmgren M, Scheffer M, Ezcurra E, Gutiérrez JR, Mohren GMJ (2001) El Niño effects on the dynamics of terrestrial ecosystems. Trends Ecol Evol 16:89-94

Hötker H (2002) Arrival of Pied Avocets Recurvirostra avosetta at the breeding site: effects of winter quarters and consequences for reproductive success. Ardea 90: 379-387

Hubálek H (2003) Spring migration of birds in relation to North Atlantic Oscillation. Folia Zool (Brno) 52:287-298

Hubálek H (2004) Global weather variability affects avian phenology: a long-term analysis, 1881-2001. Folia Zool (Brno) 53:227-236

Huin N, Sparks TH (1998) Arrival and progression of the swallow Hirundo rustica through Britain. Bird Study 45:361-370

Huin N, Sparks TH (2000) Spring arrival patterns of the cuckoo Cuculus canorus, nightingale Luscinia megarhynchos and spotted flycatcher Muscicapa striata in Britain. Bird Study 47:22-31

Hüppop O, Hüppop K (2003) North Atlantic Oscillation and timing of spring migration in birds. Proc R Soc Lond B 270:233-240

Hüppop K, Hüppop O (2005) Atlas zur Vogelberingung auf Helgoland, Teil 3: Veränderungen von Heim- und Wegzugzeiten von 1960 bis 2001. Vogelwarte 43:217-248

Hüppop O, Winkel W (2006) Climate change and timing of spring migration in the long-distance migrant Ficedula hypoleuca in central Europe: the role of spatially different temperature changes along migration routes. J Ornithol 147:344-353

Hurrell JW (1995) Decadal trends in the North Atlantic Oscillation: regional temperatures and precipitation. Science 269:676-679

Hurrell JW, Van Loon H (1997) Decadal variations in climate associated with North Atlantic Oscillation. Clim Change 36:301-326

Inouye DW, Barr B, Armitage KB, Inouye BD (2000) Climate change is affecting altitudinal migrants and hibernating species. Proc Natl Acad Sci USA 97:1630-1633

IPCC (Intergovernmental Panel on Climate Change) (2002) Climate change and biodiversity. In: Gitay H, Suárez A, Watson RT, Dokken DJ (eds) Technical Paper V of the Intergovernmental Panel on Climate Change. IPCC, Geneva

Jenkins D, Watson A (2000) Dates of first arrival and song of birds during 1974-99 in mid-Deeside, Scotland. Bird Study 47:249-251

Jenni L, Kéry M (2003) Timing of autumn bird migration under climate change: advances in long-distance migrants, delays in short-distance migrants. Proc R Soc Lond B 270: $1467-1471$

Jian-bin S, Di-qiang L, Wen-fa X (2006) A review of impacts of climate change on birds: implications of long-term studies. Zool Res 27:637-646

Jones PJ (1995) Migration strategies of Palaearctic passerines in Africa. Isr J Zool 41:393-406

Jonzén N, Lindén A, Ergon T, Knudsen E and others (2006) Rapid advance of spring arrival dates in long-distance migratory birds. Science 312:1959-1961
Jonzén N, Hendenström A, Lundberg P (2007a) Climate change and the optimal arrival of migratory birds. Proc R Soc Lond B 274:269-274

Jonzén N, Lindén A, Ergon T, Knudsen E and others (2007b) Response to comment on 'Rapid advance of spring arrival dates in long-distance migratory birds'. Science 315:598c

Kaňuščák P, Hromada M, Tryjanowski P, Sparks TH (2004) Does climate at different scales influence the phenology and phenotype of the river warbler Locustella fluviatilis? Oecologia 141:158-163

Kanyamibwa S, Schierer A, Pradel R, Lebreton JD (1990) Changes in adult annual survival rates in a western European population of the white stork Ciconia ciconia. Ibis 132:27-35

Kanyamibwa S, Bairlein F, Schierer A (1993) Comparison of survival rates between populations of the white stork Ciconia ciconia in central Europe. Ornis Scand 24:297-302

Karl TR, Jones PD, Knight RW, Kukla G and others (1993) Asymmetric trends of daily maximum and minimum temperature. Bull Am Meteorol Soc 74:1007-1023

Klein Tank AMG, Können GP, Selten FM (2005) Signals of anthropogenic influence on European warming as seen in the trend patterns of daily temperature variance. Int J Climatol 25:1-16

Knudsen E, Lindén A, Ergon T, Jonzén N and others (2007) Characterizing bird migration phenology using data from standardized monitoring at bird observatories. Clim Res 35:59-77

Kok OB, Van Ee CA, Nel DG (1991) Daylengh determines departure date of the spotted flycatcher Muscicapa striata from its wintering quarters. Ardea 79:63-66

Kokko H (1999) Competition for early arrival in migratory birds. J Anim Ecol 68:940-950

Kokko H, Gunnarsson TG, Morrell LJ, Gill JA (2006) Why do female migratory birds arrive later than males? J Anim Ecol 75:1293-1303

Kullberg C, Jakobsson S, Fransson T (2000) High migratory fuel loads impair predator evasion in sedge warblers. Auk 117:1034-1038

Lane RK, Pearman M (2003) Comparison of spring return dates of mountain bluebirds, Sialia currucoides, and tree swallows, Tachycineta bicolor, with monthly air temperatures. Can Field Nat 117:110-112

Ledneva A, Miller-Rushing AJ, Primack RB, Imbres C (2004) Climate change as reflected in a naturalist's diary, Middleborough, Massachusetts. Wilson Bull 116:224-231

Lehikoinen E, Sparks TH, Zalakevicius M (2004) Arrival and departure dates. Adv Ecol Res 35:1-31

Lind J, Fransson T, Jakobsson S, Kullberg C (1999) Reduced take-off ability in robins (Erithacus rubecula) due to migratory fuel load. Behav Ecol Sociobiol 46:65-70

Loxton RG, Sparks TH (1999) Arrival of spring migrants at Portland, Skokholm, Bardsey and Calf of Man. Bardsey Observatory Rep 42:105-142

Loxton RG, Sparks TH, Newnham JA (1998) Spring arrival dates of migrants in Sussex and Leicestershire (1966-1996). Sussex Bird Rep 50:181-196

MacMynowski DP, Root TL (2007) Climate and the complexity of migratory phenology: sexes, migratory distance, and arrival distribution. Int J Biometeorol 51:361-373

Marchant JH (1992) Recent trends in breeding populations of some common trans-Saharan migrant birds in northern Europe. Ibis 134:113-119

Marra PP, Holberton RL (1998) Corticosterone levels as indicators of habitat quality: effects of habitat segregation in a migratory bird during the non-breeding season. Oecologia 116:284-292 
Marra PP, Hobson KA, Holmes RT (1998) Linking winter and summer events in a migratory bird by using stable carbon isotopes. Science 282:1884-1886

Marra PP, Francis CM, Mulvihill RS, Moore FR (2005) The influence of climate on the timing and rate of spring bird migration. Oecologia 142:307-315

Mason CF (1995) Long-term trends in the arrival dates of spring migrants. Bird Study 42:182-189

Menzel A, Sparks TH, Estrella N, Eckhardt S (2005) 'SSW to NNE' - North Atlantic Oscillation affects the progress of seasons across Europe. Glob Change Biol 11:909-918

Menzel A, Sparks TH, Estrella N, Koch E and others (2006) European phenological response to climate change matches the warming pattern. Glob Change Biol 12: 1969-1976

Mills A (2005) Changes in the timing of spring and autumn migration in North American migrant passerines during a period of global warming. Ibis 147:259-269

Mitrus C, Tryjanowski P, Sparks TH (2005) First evidence of phenological change in a transcontinental migrant overwintering in the Indian sub-continent: the red-breasted flycatcher Ficedula parva. Ornis Fenn 82:13-19

Molina B, Del Moral JC (2005) La Cigüeña Blanca en España. VI Censo Internacional 2004. SEO/Birdlife, Madrid

Møller AP (1988) Female choice selects for male sexual tail ornaments in the monogamous barn swallow. Nature 332: 640-642

Møller AP (1994) Phenotype-dependent arrival time and its consequences in a migratory bird. Behav Ecol Sociobiol 35:115-122

Møller AP (2002) North Atlantic Oscillation (NAO) effects of climate on the relative importance of first and second clutches in a migratory passerine bird. J Anim Ecol 71: 201-210

Møller AP (2004) Protandry, sexual selection and climate change. Glob Change Biol 10:2028-2035

Møller AP (2007) Tardy females, impatient males: protandry and divergent selection on arrival date in the two sexes of the barn swallow. Behav Ecol Sociobiol 61:1311-1319

Møller AP, Merilä J (2004) Analysis and interpretation of long-term studies investigating responses to climate change. Adv Ecol Res 35:111-130

Møller AP, Szép T (2005) Rapid evolutionary change in a secondary sexual character linked to climatic change. J Evol Biol 18:481-495

Morales J, Moreno J, Merino S, Sanz JJ and others (2007) Early moult improves local survival and reduces reproductive output in female pied flycatcher. Ecoscience 14:31-39

Morbey YE, Ydenberg RC (2001) Protandrous arrival timing to breeding areas: a review. Ecol Lett 4:663-673

Moreau RE (1972) The Palaearctic-African bird migration systems. Academic Press, London

Morel GJ (1973) The Sahel zone as an environment for Palaearctic migrants. Ibis 115:413-417

Murphy-Klassen HM, Underwood TJ, Sealy SG, Czyrny AA (2005) Long-term trends in spring arrival dates of migrant birds at Delta Marsh, Manitoba, in relation to climate change. Auk 122:1130-1148

Nemani RR, Keeling CD, Hashimoto H, Jolly WM and others (2003) Climate-driven increases in global terrestrial net primary production from 1982 to 1999. Science 300: $1560-1563$

Newton I (2004) Population limitation in migrants. Ibis 146: $197-226$

Newton I (2006) Can conditions experienced during migration limit the population levels of birds? J Ornithol 147: 146-166
Newton I (2007) Weather-related mass-mortality events in migrants. Ibis 149:453-467

Nicholson SE, Tucker CJ, Ba MB (1998) Desertification, drought, and surface vegetation: an example from the West African Sahel. Bull Am Meteorol Soc 79:815-829

Nolet BA, Drent RH (1998) Bewick's swans refuelling on pondweed tubers in the Dvina Bay (White Sea) during their spring migration: first come, first served. J Avian Biol 29:574-581

Norris DR, Marra PP, Kyser TK, Sherry TW, Ratcliffe LM (2004a) Tropical winter habitat limits reproductive success on the temperate breeding grounds in a migratory bird. Proc R Soc Lond B 271:59-64

Norris DR, Marra PP, Montgomerie R, Kyser TK, Ratcliffe LM (2004b) Reproductive effort, molting latitude, and feather color in a migratory songbird. Science 306:2249-2250

Osborn TJ (2006) Recent variations in the winter North Atlantic Oscillation. Weather 61:353-355

Ottersen G, Planque B, Belgrano A, Post E, Reid PC, Stenseth NC (2001) Ecological effects of the North Atlantic Oscillation. Oecologia 128:1-14

Ottich I, Dierschke V (2003) Exploitation of resources modulates stopover behaviour of passerine migrants. J Ornithol 144:307-316

Parmesan C (2006) Ecological and evolutionary responses to recent climate change. Annu Rev Ecol Evol Syst 37: 637-669

Parmesan C, Yohe G (2003) A globally coherent fingerprint of climate change impacts across natural systems. Nature 421:37-42

Peach WJ, Baillie SR, Underhill LG (1991) Survival of British sedge warblers Acrocephalus schoenobaenus in relation to West African rainfall. Ibis 133:300-305

Peñuelas J, Filella I (2001) Responses to a warming world. Science 294:793-794

Peñuelas J, Filella I, Comas P (2002) Changed plant and animal life cycles from 1952 to 2000 in the Mediterranean region. Glob Change Biol 8:531-544

Pérez-Tris J, De la Puente J, Pinilla J, Bermejo A (2001) Body moult and autumn migration in the barn swallow Hirundo rustica: Is there a cost of moulting late? Ann Zool Fenn 38:139-148

Peron G, Henry PY, Provost P, Dehorter O, Julliard R (2007) Climate changes and post-nuptial migration strategy by two reedbed passerines. Clim Res 35:147-157

Pettorelli N, Vik JO, Mysterud A, Gaillard JM, Tucker CJ, Stenseth NC (2005) Using the satellite-derived NDVI to assess ecological responses to environmental change. Trends Ecol Evol 20:503-510

Portugal SJ, Green JA, Butler PJ (2007) Annual changes in body mass and resting metabolism in captive barnacle geese (Branta leucopsis): the importance of wing moult. J Exp Biol 210:1391-1397

Potti J (1998) Arrival time from spring migration in male pied flycatchers: individual consistency and familial resemblance. Condor 100:702-708

Ptaszyk J, Kosicki J, Sparks TH, Tryjanowski P (2003) Changes in the timing and pattern of arrival of the white stork (Ciconia ciconia) in western Poland. J Ornithol 144: 323-329

Rainio K, Laaksonen T, Ahola M, Vähätalo AV, Lehikoinen E (2006) Climatic responses in spring migration of boreal and arctic birds in relation to wintering area and taxonomy. J Avian Biol 37:507-515

Rainio K, Tøttrup AP, Lehikoinen E, Coppack T (2007) Effects of climate change on the degree of protandry in migratory songbirds. Clim Res 35:107-114 
Reichholf JH (2005) Wirkt sich die Klimaerwärmung auf die Erstankunft des Kuckucks Cuculus canorus aus? Ornithol Mitt 57:40-45

Richardson WJ (1978) Timing and amount of bird migration in relation to weather: a review. Oikos 30:224-272

Richardson WJ (1990) Timing of bird migration in relation to weather: updated review. In: Gwinner E (ed) Bird migration. Physiology and ecophysiology. Springer Verlag, Berlin, p 78-101

Rodríguez-Teijeiro JD, Gordo O, Puigcerver M, Gallego S, Vinyoles D, Ferrer X (2005) African climate warming advances spring arrival of the common quail Coturnix coturnix. Ardeola 52:159-162

Root TL, Price JT, Hall KR, Schneider SH, Rosenzweig C, Pounds JA (2003) Fingerprints of global warming on wild animals and plants. Nature 421:57-60

Root TL, MacMynowski DP, Mastrandrea MD, Schneider SH (2005) Human-modified temperatures induce species changes: joint attribution. Proc Natl Acad Sci USA 102: 7465-7469

Rubolini D, Massi A, Spina F (2002) Replacement of body feathers is associated with low premigratory energy stores in a long-distance migratory bird, the barn swallow (Hirundo rustica). J Zool (Lond) 258:441-447

Rubolini D, Ambrosini R, Caffi M, Brichetti P, Armiraglio S, Saino N (2007a) Long-term trends in first arrival and first egg laying dates of some migrant and resident bird species in northern Italy. Int J Biometeorol 51:553-563

Rubolini D, Møller AP, Rainio K, Lehikoinen E (2007b) Intraspecific consistency and geographic variability in temporal trends of spring migration phenology among European bird species. Clim Res 35:135-146

Russell RW, Carpenter FL, Hixon MA, Paton DC (1994) The impact of variation in stopover habitat quality on migrant rufuous hummingbirds. Conserv Biol 8:483-490

Sæther BE, Grøtan V, Tryjanowski P, Barbraud C, Engen S, Fulin M (2006) Climate and spatio-temporal variation in the population dynamics of a long distance migrant, the white stork. J Anim Ecol 75:80-90

Saino N, Szép T, Ambrosini R, Romano M, Møller AP (2004a) Ecological conditions during winter affect sexual selection and breeding in a migratory bird. Proc R Soc Lond B 271: 681-686

Saino N, Szép T, Romano M, Rubolini D, Spina F, Møller AP (2004b) Ecological conditions during winter predict arrival date at the breeding quarters in a trans-Saharan migratory bird. Ecol Lett 7:21-25

Saino N, Rubolini D, Jonzén N, Ergon T, Montemaggiori A, Stenseth NC, Spina F (2007) Temperature and rainfall anomalies in Africa predict timing of spring migration in trans-Saharan migratory birds. Clim Res 35:123-134

Salewski V, Jones P (2006) Palearctic passerines in Afrotropical environments: a review. J Ornithol 147:192-201

Salewski V, Bairlein F, Leisler B (2000a) Recurrence of some Palearctic migrant passerine species in West Africa. Ringing Migr 20:29-30

Salewski V, Bairlein F, Leisler B (2000b) Site-fidelity of Palearctic passerine migrants in the northern Guinea savanna zone, West Africa. Vogelwarte 40:298-301

Salewski V, Altwegg R, Erni B, Falk KH, Bairlein F, Leisler B (2004) Moult of three Palearctic migrants in their West African winter quarters. J Ornithol 145:109-116

Sanz JJ (2002) Climate change and birds: Have their ecological consequences already been detected in the Mediterranean region? Ardeola 49:109-120

Schaub M, Jenni L (2001) Variation of fuelling rates among sites, days and individuals in migrating passerine birds.
Funct Ecol 15:584-594

Schieltz PC, Murphy ME (1995) Diurnal variation in oxygen consumption by molting and nonmolting sparrows. Comp Biochem Physiol A 112:265-272

Schwartz MD, Ahas R, Aasa A (2006) Onset of spring starting earlier across the Northern Hemisphere. Glob Change Biol 12:343-351

Serra L, Griggo M, Licheri D, Pilastro A (2007) Moult speed constrains the expression of a carotenoid-based sexual ornament. J Evol Biol 20:2028-2034

Shamoun-Baranes J, Van Loon E, Alon D, Alpert P, Yom-Tov Y, Leshem Y (2006) Is there a connection between weather at departure sites, onset of migration and timing of soaring-bird autumn migration in Israel? Glob Ecol Biogeogr 15:541-552

Sherry TW, Holmes RT (1996) Winter habitat quality, population limitation, and conservation of Neotropical-Nearctic migrant birds. Ecology 77:36-48

Sillett TS, Holmes RT, Sherry TW (2000) Impacts of a global climate cycle on population dynamics of a migratory songbird. Science 288:2040-2042

Sinelschikova A, Sokolov LV (2004) Long-term monitoring of the timing of migration in thrushes (Turdus philomelos, T. iliacus) in the eastern Baltic. Avian Ecol Behav 12: $11-30$

Sinelschikova A, Kosarev V, Panov I, Baushev AN (2007) The influence of wind conditions in Europe on the advance in timing of the spring migration of the song thrush (Turdus philomelos) in the south-east Baltic region. Int $\mathrm{J}$ Biometeorol 51:431-440

Sokolov LV (2000) Spring ambient temperature as an important factor controlling timing of arrival, breeding, postfledging dispersal and breeding success of pied flycatchers Ficedula hypoleuca in eastern Baltic. Avian Ecol Behav 5:79-104

Sokolov LV (2006) Influence of the global warming on the timing of migration and breeding of passerines in the 20th century. Zool Zh 85:317-342

Sokolov LV, Kosarev VV (2003) Relationship between timing of arrival of passerines to the Courish Spit and the North Atlantic Oscillation index (NAOI) and precipitation in Africa. Proc Zool Inst Russ Acad Sci 299:141-154

Sokolov LV, Markovets MY, Shapoval AP, Morozov YG (1998) Long-term trends in the timing of spring migration of passerines on the Courish Spit of the Baltic Sea. Avian Ecol Behav 1:1-21

Sokolov LV, Markovets MY, Morozov YG (1999) Long-term dynamics of the mean date of autumn migration in passerines on the Courish Spit of the Baltic Sea. Avian Ecol Behav 2:1-18

Southern HN (1938) The spring migration of the swallow over Europe. Br Birds 32:4-7

Sparks TH (1999) Phenology and the changing pattern of bird migration in Britain. Int J Biometeorol 42:134-138

Sparks TH, Braslavská O (2001) The effects of temperature, altitude and latitude on the arrival and departure of the swallow Hirundo rustica in the Slovak Republic. Int J Biometeorol 45:212-216

Sparks TH, Carey PD (1995) The response of species to climate over two centuries: an analysis of the Marsham phenological record 1736-1947. J Ecol 83:321-329

Sparks TH, Crick HQP (1999) The times they are a-changing? Bird Conserv Int 9:1-7

Sparks TH, Mason CF (2001) Dates of arrivals and departures of spring migrants taken from Essex Bird Reports 1950-1998. Essex Bird Report 1999:154-164

Sparks TH, Mason CF (2004) Can we detect change in the 
phenology of winter migrant birds in the UK? Ibis 146:57-60

Sparks TH, Menzel A (2002) Observed changes in seasons: an overview. Int J Climatol 22:1715-1725

Sparks TH, Tryjanowski P (2007) Patterns of spring arrival dates differ in two hirundines. Clim Res 35:159-164

Sparks TH, Roberts DR, Crick HQP (2001) What is the value of first arrival dates of spring migrants in phenology? Avian Ecol Behav 7:75-85

Sparks TH, Bairlein F, Bojarinova JG, Hüppop O and others (2005) Examining the total arrival distribution of migratory birds. Glob Change Biol 11:22-30

Sparks TH, Huber K, Bland RL, Crick HQP and others (2007) How consistent are trends in arrival (and departure) dates of migrant birds in the UK? J Ornithol 148:503-511

Spottiswoode CN, Tøttrup AP, Coppack T (2006) Sexual selection predicts advancement of avian spring migration in response to climate change. Proc R Soc Lond B 273: 3023-3029

Stenseth NC, Mysterud A (2005) Weather packages: finding the right scale and composition of climate in ecology. J Anim Ecol 74:1195-1198

Stenseth NC, Ottersen G, Hurrell JW, Mysterud A and others (2003) Studying climate effects on ecology through the use of climate indices: the North Atlantic Oscillation, El Niño Southern Oscillation and beyond. Proc R Soc Lond B 270: 2087-2096

Stervander M, Lindström Å, Jonzén N, Andersson A (2005) Timing of spring migration in birds: long-term trends, North Atlantic Oscillation and the significance of different migration routes. J Avian Biol 36:210-221

Strode PK (2003) Implications of climate change for North American wood warblers (Parulidae). Glob Change Biol 9: $1137-1144$

Studds CE, Marra PP (2007) Linking fluctuations in rainfall to nonbreeding season performance in a long-distance migratory bird, Septophaga ruticilla. Clim Res 35:115-122

Sueur F, Triplet P (2001) Réchauffement climatique: Les passereaux arrivent-ils plus tôt au printemps? Avifaune Picarde 11:111-120

Svensson SE (1985) Effects of changes in tropical environments on the north European avifauna. Ornis Fenn 62:56-63

Svensson E, Nilsson JA (1997) The trade-off between molt and parental care: A sexual conflict in the blue tit? Behav Ecol 8:92-98

Swaddle JP, Witter MS, Cuthill IC, Budden A, McCowen P (1996) Plumage condition affects flight performance in common starlings: implications for developmental homeostasis, abrasion and molt. J Avian Biol 27:103-111

Szép T (1995) Relationship between West African rainfall and the survival of the Central European adult sand martin Riparia riparia population. Ibis 137:162-168

Szép T, Møller AP (2005) Using remote sensing to identify migration and wintering areas, and to analyze effects of environmental conditions on migratory birds. In: Greenberg R, Marra PP (eds) Birds of two worlds. Johns Hopkins University Press, Baltimore, p 390-400

Szép T, Møller AP, Piper S, Nutall R, Szabó ZD, Pap PL (2006) Searching for potential wintering and migration areas of a Danish barn swallow population in South Africa by correlating NDVI with survival estimates. J Ornithol 147: 245-253

Tøttrup AP, Thorup K, Rahbek C (2006a) Patterns of change in timing of spring migration in North European songbird populations. J Avian Biol 37:84-92
Tøttrup AP, Thorup K, Rahbek C (2006b) Changes in timing of autumn migration in North European songbird populations. Ardea 94:527-536

Tryjanowski P, Sparks TH (2001) Is the detection of the first arrival date of migrating birds influenced by population size? A case study of the red-backed shrike Lanius collurio. Int J Biometeorol 45:217-219

Tryjanowski P, Kuźniak S, Sparks TH (2002) Earlier arrival of some farmland migrants in western Poland. Ibis 144:62-68

Tryjanowski P, Kuźniak S, Sparks TH (2005) What affects the magnitude of change in first arrival dates of migrant birds? J Ornithol 146:200-205

Underhill LG, Prys-Jones RP, Dowsett RJ, Herroelen P and others (1992) The biannual primary moult of willow warblers Phylloscopus trochilus in Europe and Africa. Ibis 134:286-297

Vähätalo AV, Rainio K, Lehikoinen A, Lehikoinen E (2004) Spring arrival of birds depends on the North Atlantic Oscillation. J Avian Biol 35:210-216

Van den Brink B, Bijlsma RG, Van der Have TM (2000) European swallows Hirundo rustica in Botswana during three non-breeding seasons: the effects of rainfall on moult. Ostrich 71:198-204

Vicente-Serrano SM, Heredia-Laclaustra A (2004) NAO influence on NDVI trends in the Iberian Peninsula (19822000). Int J Remote Sens 25:2871-2879

Visbeck MH, Hurrell JW, Polvani L, Cullen HM (2001) The North Atlantic Oscillation: past, present, and future. Proc Natl Acad Sci USA 98:12876-12877

Visser ME, Both C (2005) Shifts in phenology due to global climate change: the need for a yardstick. Proc R Soc Lond B Bio 272:2561-2569

Walther BA, Rahbek C (2002) Where do Palearctic migratory birds overwinter in Africa? Danks Orn Foren Tidsskr 96:4-8

Walther GR, Post E, Convey P, Menzel A and others (2002) Ecological response to recent climate change. Nature 416:389-395

Walther BA, Wisz MS, Rahbek C (2004) Known and predicted African winter distributions and habitat use of the endangered Basra reed warbler (Acrocephalus griseldis) and the near-threatened cinereous bunting (Emberiza cineracea). J Ornithol 145:287-299

Weidinger K, Král M (2007) Climatic effects on arrival and laying dates in a long-distance migrant, the collared flycatcher Ficedula albicollis. Ibis 149:836-847

Wilson WH, Kipervaser D, Lilley SA (2000) Spring arrival dates of Maine migratory breeding birds: 1994-1997 vs. 1899-1911. Northeastern Nat 7:1-6

Winstanley D, Spencer R, Williamson K (1974) Where have all the whitethroats gone? Bird Study 21:1-14

Witt K (2004) Erst-und Letztbeobachtungen des Mauerseglers (Apus apus) in Berlin. Berl Ornithol Ber 14:186-192

Yosef R, Markovets M, Mitchell L, Tryjanowski P (2006) Body condition as a determinant for stopover in bee-eaters (Merops apiaster) on spring migration in the Arava Valley, southern Israel. J Arid Environ 64:401-411

Zalakevicius M (2001) Bird migration and the climate: a review of the studies conducted in Lithuania in the context of climate change. Acta Zool Lituanica 11:200-218

Zalakevicius M, Bartkeviciene G, Raudonikis L, Janulaitis J (2006) Spring arrival response to climate change in birds: a case study from eastern Europe. J Ornithol 147: $326-343$

Zeng N (2003) Drought in Sahel. Science 302:999-1000 
Appendix 1. List of studies used for the quantitative assessment of climatic variables classified in each of the categories defined for Figs. 5a to e. In the case of Fig. 5d, the exact number of months used in each study is shown

\begin{tabular}{|c|c|c|c|c|c|c|c|c|c|c|c|c|c|c|c|c|c|c|}
\hline \multirow[t]{2}{*}{ Source } & \multicolumn{6}{|c|}{$\begin{array}{l}\text { Type of explanatory } \\
\text { variable (Fig. 5a) }\end{array}$} & \multicolumn{3}{|c|}{$\begin{array}{c}\text { Geographical } \\
\text { origin } \\
\text { (Fig. } 5 b)\end{array}$} & \multicolumn{3}{|c|}{$\begin{array}{l}\text { Temporal } \\
\text { definition } \\
\text { (Fig. 5c) }\end{array}$} & \multicolumn{2}{|c|}{$\begin{array}{l}\text { No. of } \\
\text { months } \\
\text { (Fig. 5d) }\end{array}$} & \multicolumn{4}{|c|}{$\begin{array}{l}\text { Month } \\
\text { (Fig. 5e) }\end{array}$} \\
\hline & हृ & $\underset{D}{\mathscr{D}}$ & 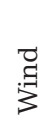 & 足 & 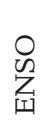 & 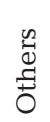 & $\begin{array}{l}\overrightarrow{0} \\
0 \\
0 \\
0\end{array}$ & 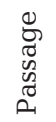 & 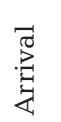 & $\stackrel{\vec{\nexists}}{\stackrel{\nexists}{\theta}}$ & 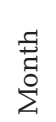 & 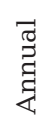 & 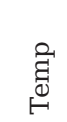 & $\stackrel{\bigcirc}{\bigcirc}$ & 0 & $\dashv$ & 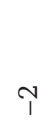 & $m_{1}$ \\
\hline Ahas \& Aasa (2006) & & & & $\mathrm{X}$ & & & & & & & $\mathrm{X}$ & & & 1,3 & & & & \\
\hline Ahola et al. (2004) & $\mathrm{X}$ & & & $\mathrm{X}$ & & & & $\mathrm{X}$ & $\mathrm{X}$ & $\mathrm{X}$ & $\mathrm{X}$ & & & 4 & & & & \\
\hline Askeyev et al. (2007) & $\mathrm{X}$ & & & & & & & & $\mathrm{X}$ & & $\mathrm{X}$ & & 1 & & $\mathrm{X}$ & $\mathrm{X}$ & & \\
\hline Barbraud \& Weimerskirch (2006) & $\mathrm{X}$ & & & & $\mathrm{X}$ & $\mathrm{X}$ & & & $\mathrm{X}$ & & $\mathrm{X}$ & & 1 & & $\mathrm{X}$ & & & \\
\hline Barrett (2002) & $\mathrm{X}$ & & & & & & & & $\mathrm{X}$ & & $\mathrm{X}$ & & 1 & & $\mathrm{X}$ & & & \\
\hline Beaumont et al. (2006) & $\mathrm{X}$ & $\mathrm{X}$ & & & & & & & $\mathrm{X}$ & & $\mathrm{X}$ & & 3 & & & & & \\
\hline Both \& Visser (2001) & $\mathrm{X}$ & & & & & & & & $\mathrm{X}$ & & $\mathrm{X}$ & & 1 & & $\mathrm{X}$ & & & \\
\hline Both et al. (2005) & $\mathrm{X}$ & & & & & & & $\mathrm{X}$ & $\mathrm{X}$ & & $\mathrm{X}$ & & 1 & & & $\mathrm{X}$ & & \\
\hline Boyd (2003) & $\mathrm{X}$ & $\mathrm{X}$ & $\mathrm{X}$ & $\mathrm{X}$ & & $\mathrm{X}$ & $\mathrm{X}$ & $\mathrm{X}$ & $\mathrm{X}$ & & $\mathrm{X}$ & & 1 & 1,4 & & & & \\
\hline Bradley et al. (1999) & $\mathrm{X}$ & & & & & & & & $\mathrm{X}$ & & $\mathrm{X}$ & & 1 & & & & & \\
\hline Browne \& Aebischer (2003) & $\mathrm{X}$ & & & & & & & & $\mathrm{X}$ & & $\mathrm{X}$ & & 1 & & $\mathrm{X}$ & $\mathrm{X}$ & & \\
\hline Butler (2003) & $\mathrm{X}$ & & & & & & & & $\mathrm{X}$ & & $\mathrm{X}$ & & 1 & & & & & \\
\hline Chambers (2005) & $\mathrm{X}$ & $\mathrm{X}$ & & & & & & $\mathrm{X}$ & $\mathrm{X}$ & & & $\mathrm{X}$ & & & & & & \\
\hline Cotton (2003) & $\mathrm{X}$ & & & $\mathrm{X}$ & $\mathrm{X}$ & & $\mathrm{X}$ & & & & $\mathrm{X}$ & & 3 & 3 & & & & \\
\hline Croxton et al. (2006) & $\mathrm{X}$ & & & & & & & $\mathrm{X}$ & $\mathrm{X}$ & & $\mathrm{X}$ & & 1 & & $\mathrm{X}$ & $\mathrm{X}$ & $\mathrm{X}$ & $\mathrm{X}$ \\
\hline Dolenec (2003) & $\mathrm{X}$ & & & & & & & & $\mathrm{X}$ & & $\mathrm{X}$ & & 3 & & & & & \\
\hline Forchhammer et al. (2002) & & & & $\mathrm{X}$ & & & & & & & $\mathrm{X}$ & & & 4 & & & & \\
\hline Gordo \& Sanz (2006a) & $\mathrm{X}$ & $\mathrm{X}$ & & & & & $\mathrm{X}$ & & $\mathrm{X}$ & & $\mathrm{X}$ & & 2 & & $\mathrm{X}$ & $\mathrm{X}$ & & \\
\hline Gordo et al. (2005) & $\mathrm{X}$ & $\mathrm{X}$ & & & & & $\mathrm{X}$ & & $\mathrm{X}$ & & $\mathrm{X}$ & $\mathrm{X}$ & 2 & & $\mathrm{X}$ & $\mathrm{X}$ & & \\
\hline Hubálek (2003) & & & & $\mathrm{X}$ & & & & & & & & $\mathrm{X}$ & & 3 & & & & \\
\hline Hubálek (2004) & & & & $\mathrm{X}$ & & & & & & & & $\mathrm{X}$ & & 3,4 & & & & \\
\hline Huin \& Sparks (1998) & $\mathrm{X}$ & $\mathrm{X}$ & & & & & & $\mathrm{X}$ & $\mathrm{X}$ & & $\mathrm{X}$ & & 1 & & $\mathrm{X}$ & & & \\
\hline Huin \& Sparks (2000) & $\mathrm{X}$ & $\mathrm{X}$ & & & & & & $\mathrm{X}$ & $\mathrm{X}$ & & $\mathrm{X}$ & & 1 & & $\mathrm{X}$ & & & \\
\hline Нüррор \& Нüррор (2003) & $\mathrm{X}$ & & & $\mathrm{X}$ & & & & & $\mathrm{X}$ & $\mathrm{X}$ & $\mathrm{X}$ & & & 4 & & & & \\
\hline Hüppop \& Hüppop (2005) & $\mathrm{X}$ & & & $\mathrm{X}$ & & & & & $\mathrm{X}$ & $\mathrm{X}$ & $\mathrm{X}$ & & & 4 & & & & \\
\hline Hüppop \& Winkel (2006) & $\mathrm{X}$ & & & & & & & $\mathrm{X}$ & $\mathrm{X}$ & $\mathrm{X}$ & & & & & & & & \\
\hline Inouye et al. (2000) & & & & & & $\mathrm{X}$ & & & & & & & & & & & & \\
\hline Jenkins \& Watson (2000) & $\mathrm{X}$ & & & & & & & & $\mathrm{X}$ & & & & & & & & & \\
\hline Jonzén et al. (2006) & & & & $\mathrm{X}$ & & & & & & & $\mathrm{X}$ & & & 4 & & & & \\
\hline Kaňuščák et al. (2004) & $\mathrm{X}$ & $\mathrm{X}$ & & $\mathrm{X}$ & & & $\mathrm{X}$ & $\mathrm{X}$ & $\mathrm{X}$ & & $\mathrm{X}$ & & 1,4 & 4 & $\mathrm{X}$ & & & \\
\hline Lane \& Pearman (2003) & $\mathrm{X}$ & & & & & & & & $\mathrm{X}$ & & $\mathrm{X}$ & & 1 & & $\mathrm{X}$ & & & \\
\hline Ledneva et al. (2004) & $\mathrm{X}$ & & & & & & & & $\mathrm{X}$ & & $\mathrm{X}$ & & 2 & & $\mathrm{X}$ & $\mathrm{X}$ & & \\
\hline Lehikoinen et al. (2004) & $\mathrm{X}$ & & & & & & & & $\mathrm{X}$ & & $\mathrm{X}$ & & 1 & & & $\mathrm{X}$ & & \\
\hline Loxton \& Sparks (1999) & $\mathrm{X}$ & & & & & & & & $\mathrm{X}$ & & $\mathrm{X}$ & & 1,2 & & $\mathrm{X}$ & $\mathrm{X}$ & $\mathrm{X}$ & \\
\hline Loxton et al. (1998) & $\mathrm{X}$ & & & & & & & & $\mathrm{X}$ & & $\mathrm{X}$ & & 1,2 & & $\mathrm{X}$ & $\mathrm{X}$ & $\mathrm{X}$ & \\
\hline MacMynowski \& Root (2007) & $\mathrm{X}$ & & & $\mathrm{X}$ & $\mathrm{X}$ & & & & $\mathrm{X}$ & & $\mathrm{X}$ & & 1 & 1 & $\mathrm{X}$ & $\mathrm{X}$ & & \\
\hline Marra et al. (2005) & $\mathrm{X}$ & & & $\mathrm{X}$ & & $\mathrm{X}$ & & & $\mathrm{X}$ & & $\mathrm{X}$ & & 2 & 4 & $\mathrm{X}$ & $\mathrm{X}$ & & \\
\hline Mason (1995) & $\mathrm{X}$ & & & & & & & & $\mathrm{X}$ & & $\mathrm{X}$ & & 1 & & $\mathrm{X}$ & $\mathrm{X}$ & & \\
\hline Mitrus et al. (2005) & $\mathrm{X}$ & & & & & & $\mathrm{X}$ & $\mathrm{X}$ & $\mathrm{X}$ & & $\mathrm{X}$ & & 1 & & & $\mathrm{X}$ & & \\
\hline Murphy-Klassen et al. (2005) & $\mathrm{X}$ & & & & & & & & $\mathrm{X}$ & & $\mathrm{X}$ & & 1 & & $\mathrm{X}$ & & & \\
\hline Ptaszyk et al. (2003) & $\mathrm{X}$ & & & & & & & & $\mathrm{X}$ & & $\mathrm{X}$ & & 2 & & $\mathrm{X}$ & $\mathrm{X}$ & & \\
\hline Rainio et al. (2006) & & & & $\mathrm{X}$ & & & & & & & $\mathrm{X}$ & & & 4 & & & & \\
\hline Rodríguez-Teijeiro et al. (2005) & $\mathrm{X}$ & & & & & & $\mathrm{X}$ & $\mathrm{X}$ & $\mathrm{X}$ & & $\mathrm{X}$ & & 1 & & $\mathrm{X}$ & $\mathrm{X}$ & & \\
\hline Rubolini et al. (2007a) & $\mathrm{X}$ & $\mathrm{X}$ & & $\mathrm{X}$ & & & & & $\mathrm{X}$ & & $\mathrm{X}$ & & 1 & 3 & $\mathrm{X}$ & & & \\
\hline Saino et al. (2004b) & & & & & & $\mathrm{X}$ & $\mathrm{X}$ & & & & $\mathrm{X}$ & & & & & & & \\
\hline Sinelschikova et al. (2007) & $\mathrm{X}$ & $\mathrm{X}$ & $\mathrm{X}$ & & & & $\mathrm{X}$ & $\mathrm{X}$ & & & $\mathrm{X}$ & & 1 & & $\mathrm{X}$ & $\mathrm{X}$ & $\mathrm{X}$ & $\mathrm{X}$ \\
\hline Sokolov \& Kosarev (2003) & $\mathrm{X}$ & $\mathrm{X}$ & & $\mathrm{X}$ & & & $\mathrm{X}$ & $\mathrm{X}$ & $\mathrm{X}$ & & $\mathrm{X}$ & & 1 & 1,3 & $\mathrm{X}$ & $\mathrm{X}$ & $\mathrm{X}$ & $\mathrm{X}$ \\
\hline Sokolov (2000) & $\mathrm{X}$ & & & & & & & & $\mathrm{X}$ & & $\mathrm{X}$ & & 1 & & $\mathrm{X}$ & $\mathrm{X}$ & & \\
\hline Sokolov (2006) & $\mathrm{X}$ & $\mathrm{X}$ & & $\mathrm{X}$ & & $\mathrm{X}$ & $\mathrm{X}$ & $\mathrm{X}$ & $\mathrm{X}$ & & $\mathrm{X}$ & & 1 & 2 & $\mathrm{X}$ & $\mathrm{X}$ & & \\
\hline Sokolov et al. (1998) & $\mathrm{X}$ & & & & & & & & $\mathrm{X}$ & & $\mathrm{X}$ & & 1 & & $\mathrm{X}$ & $\mathrm{X}$ & & \\
\hline Sparks \& Braslavská (2001) & $\mathrm{X}$ & & & & & & & & $\mathrm{X}$ & & $\mathrm{X}$ & & 1 & & $\mathrm{X}$ & & & \\
\hline Sparks \& Carey (1995) & $\mathrm{X}$ & $\mathrm{X}$ & & & & & & & $\mathrm{X}$ & & $\mathrm{X}$ & $\mathrm{X}$ & 1 & & $\mathrm{X}$ & $\mathrm{X}$ & $\mathrm{X}$ & $\mathrm{X}$ \\
\hline Sparks \& Mason (2001) & $\mathrm{X}$ & & & & & & & & $\mathrm{X}$ & & $\mathrm{X}$ & & 3 & & & & & \\
\hline Sparks et al. (2005) & $\mathrm{X}$ & & & $\mathrm{X}$ & & & & & $\mathrm{X}$ & & $\mathrm{X}$ & & 1 & 4 & $\mathrm{X}$ & $\mathrm{X}$ & $\mathrm{X}$ & \\
\hline Sparks et al. (2007) & $\mathrm{X}$ & & & & & & & $\mathrm{X}$ & $\mathrm{X}$ & & $\mathrm{X}$ & & 1 & & $\mathrm{X}$ & $\mathrm{X}$ & $\mathrm{X}$ & \\
\hline Stervander et al. (2005) & & & & $\mathrm{X}$ & & & & & & & $\mathrm{X}$ & & & 4 & & & & \\
\hline Strode (2003) & $\mathrm{X}$ & & & & & & & $\mathrm{X}$ & $\mathrm{X}$ & $\mathrm{X}$ & & & & & & & & \\
\hline Sueur \& Triplet (2001) & $\mathrm{X}$ & & & & & & & & $\mathrm{X}$ & & $\mathrm{X}$ & & 1 & & $\mathrm{X}$ & & & \\
\hline Tryjanowski et al. (2002) & $\mathrm{X}$ & & & & & & & & $\mathrm{X}$ & & $\mathrm{X}$ & & 1 & & $\mathrm{X}$ & $\mathrm{X}$ & $\mathrm{X}$ & \\
\hline Vähätalo et al. (2004) & & & & $\mathrm{X}$ & & & & & & & $\mathrm{X}$ & & & 4 & & & & \\
\hline Weidinger \& Král (2007) & $\mathrm{X}$ & & & $\mathrm{X}$ & & & $\mathrm{X}$ & $\mathrm{X}$ & $\mathrm{X}$ & & $\mathrm{X}$ & & 1 & 4 & $\mathrm{X}$ & & & \\
\hline Zalakevicius et al. (2006) & $\mathrm{X}$ & $\mathrm{X}$ & & $\mathrm{X}$ & & $\mathrm{X}$ & $\mathrm{X}$ & $\mathrm{X}$ & $\mathrm{X}$ & & $\mathrm{X}$ & & 1 & 3 & $\mathrm{X}$ & $\mathrm{X}$ & & \\
\hline
\end{tabular}

